Review

\title{
Gas-solid catalytic reactions over ruthenium-based catalysts
}

\author{
Wenbo Shi a,b, $†$, Xiaolong Liu ${ }^{b, \dagger}$, Junlin Zeng b, Jian Wang ${ }^{b}$, Yaodong Wei ${ }^{\mathrm{a}, *}$, Tingyu Zhu ${ }^{\mathrm{b}, \#}$ \\ a State Key Laboratory of Heavy Oil Processing, China University of Petroleum (Beijing), Beijing 102249, China \\ b National Engineering Laboratory for Hydrometallurgical Cleaner Production Technology, Institute of Process Engineering, Chinese Academy of Sciences, \\ Beijing 100190, China
}

\section{A R T I C L E I N F O}

Article history:

Received 28 March 2016

Accepted 28 April 2016

Published 5 August 2016

\section{Keywords:}

Gas-solid catalytic reaction

Ruthenium

Volatile organic compound

Catalytic oxidation

Preferential CO oxidation

HCl oxidation

\begin{abstract}
A B S T R A C T
Ruthenium (Ru)-based catalysts are widely employed in several types of gas-solid reactions because of their high catalytic activities. This review provides theoretical research on Ru-based catalysts and an analysis of their basic properties and oxidation behavior. There is particular emphasis on Ru-catalyzed gas-solid catalytic reactions, including the catalytic oxidation of VOCs, preferential oxidation of $\mathrm{CO}$, synthesis of ammonia, oxidation of $\mathrm{HCl}$ and partial oxidation of $\mathrm{CH}_{4}$. Recent literature on catalysis is summarized and compared. Finally, we describe current challenges in the field and propose approaches for future development of Ru-based catalysts.
\end{abstract}

(C) 2016, Dalian Institute of Chemical Physics, Chinese Academy of Sciences. Published by Elsevier B.V. All rights reserved.

of catalytic performance - including the study of elementary reactions steps, reaction intermediates and related topics - is typically accomplished via a combination of surface science and experimental methods. Such studies have led to an in-depth understanding of catalytic reactions under real-life conditions.

Many catalysts, such as noble metals and transition metal oxides, have been explored for gas-solid reactions. Recently, supported ruthenium (Ru)-based catalysts were employed in many gas-solid reactions because of their excellent activities under low temperature and pressure conditions.

This review describes properties of $\mathrm{Ru}$, the oxidation of $\mathrm{Ru}$ metal and the theoretical research on Ru-based catalysts. In addition, we explain the gas-solid reactions catalyzed by Ru-based materials. As shown in Fig. 1, the catalytic applica-

\footnotetext{
* Corresponding author. Tel/Fax: +86-10-89733939; E-mail: weiyd@cup.edu.cn

\# Corresponding author. Tel/Fax: +86-10-82544821; E-mail: tyzhu@ipe.ac.cn

† These authors contributed equally to this work.

This work was supported by Beijing Natural Science Foundation (8164063) and the Strategic Priority Research Program of the Chinese Academy of Sciences (XDB05050100).

DOI: 10.1016/S1872-2067(15)61124-X | http://www.sciencedirect.com/science/journal/18722067 | Chin. J. Catal., Vol. 37, No. 8, August 2016
} 


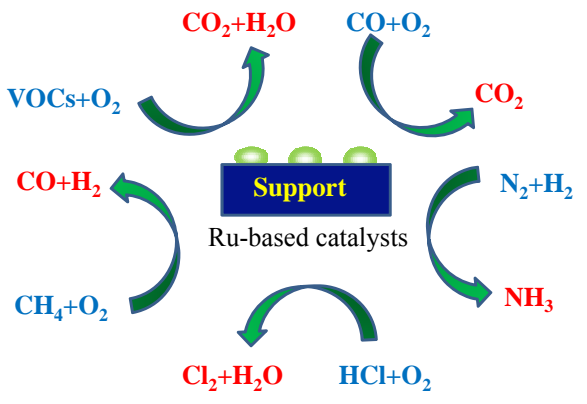

Fig. 1. Gas-solid reactions promoted by Ru-based catalysts.

tions of these materials include the catalytic oxidation of volatile organic compounds (VOCs) [3-5], preferential oxidation of CO (PROX) [6,7], synthesis of ammonia [8], oxidation of $\mathrm{HCl}$ (the Deacon process) [9] and partial oxidation of $\mathrm{CH}_{4}$ [10-12]. Finally, this review summarizes existing problems as well as future developmental trends for Ru-based catalysts.

\section{Ru-based catalysts}

\subsection{Basic properties}

$\mathrm{Ru}$ is a rare transition metal belonging to the platinum group in the periodic table. The electronic structure of elemental Ru is $4 d^{7} 5 s^{1}$ and Ru exhibits a rich variety of oxidation states, including $+2,+3,+4,+6$ and +8 . Ru materials are mainly composed of metallic $\mathrm{Ru}, \mathrm{RuO}_{2}$ and $\mathrm{RuO}_{4}$. The boiling points of these forms are $4100{ }^{\circ} \mathrm{C}[13,14], 1400{ }^{\circ} \mathrm{C}$ and $100{ }^{\circ} \mathrm{C}[15,16]$, respectively. The crystal planes of $\mathrm{RuO}_{2}$ are illustrated in Fig. 2. In the bulk structure of $\mathrm{RuO}_{2}$ (rutile structure), the $\mathrm{Ru}$ atoms bind to six oxygen atoms, forming a slightly distorted $\mathrm{RuO}_{6}$ octahedron, while the oxygen atoms are coordinated to three $\mathrm{Ru}$ atoms in a planar configuration that is consistent with the $s p^{2}$ hybridization of oxygen [1].

Volatility at high temperature is recognized as a serious limitation in applications of Ru-based catalysts. In Ru-based catalysts for gas-solid reactions, metallic $\mathrm{Ru}$ and/or $\mathrm{RuO}_{2}$ have been commonly identified as the active species and the reaction temperatures are usually below $400{ }^{\circ} \mathrm{C}$, much lower than the boiling points of $\mathrm{Ru}$ and $\mathrm{RuO}_{2}$. Hence, volatility of $\mathrm{Ru}$ species is not observed in most gas-solid catalytic reactions and there have been no reports of this behavior for such reactions.

\subsection{Oxidation behaviors}

The transition from oxygen adsorption to oxide formation on $\mathrm{Ru}$ is structurally complex because of the various phases of

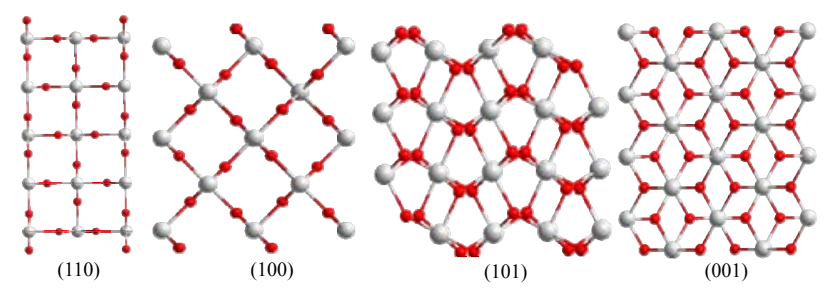

Fig. 2. The crystal planes of $\mathrm{RuO}_{2}$. oxygen on the surface [17]. However, the orientation of the $\mathrm{RuO}_{2}$ depends on the orientation of the $\mathrm{Ru}$. H. Over et al. [18] demonstrated that the active part of this "O-rich" $\mathrm{Ru}$ phase is $\mathrm{RuO}_{2}$, which grows epitaxially with its (110) plane parallel to the $\mathrm{Ru}(0001)$ surface at high $\mathrm{O}_{2}$ partial pressure and elevated temperatures. When the $\mathrm{Ru}(0001)$ surface is exposed to molecular oxygen under UHV conditions, a $(2 \times 2)-0$ layer and a $(2 \times 1)-0$ overlayer are formed [19]. At much higher concentrations of oxygen, for example, more than $1000 \mathrm{~L}$ at room temperature, the $\mathrm{Ru}(0001)$ surface stabilizes two additional phases of chemisorbed oxygen, namely, $(2 \times 2)-30$ and $(1 \times 1)-0$ [20]. However, Ru (0001) is oxidized by an autocatalytic process, because of formation of oxide nuclei on the $\mathrm{Ru}(0001)-(1 \times 1) 0$ surface [17]. The autocatalytic reaction indicates that the surface produces its own 'catalyst', thus readily dissociating the oxygen molecules and resulting in self-acceleration of the oxidation process [21]. This complexity is characteristic of oxygen chemistry on many transition metal surfaces, as shown in Fig. 3. The oxidation of $\mathrm{Ru}$ occurs only under specific conditions and requires a minimum threshold temperature. Goodman et al. [22] discovered that formation of $\mathrm{RuO}_{2}$ on $\mathrm{Ru}$ (0001) required, at a minimum, an $\mathrm{O}_{2} / \mathrm{CO}$ pressure ratio of $18 / 10$, a temperature of $360{ }^{\circ} \mathrm{C}$, and a reaction time of $700 \mathrm{~s}$. To generate $\mathrm{RuO}_{2}$, the oxygen must cover a volume of $4 \mathrm{ML}$ and must have at least two layers of the tri-layer structure [23].

\subsection{Theoretical research}

Relatively simple reaction structures are usually chosen to represent the atomic-scale structure of the catalyst for study. CO oxidation is one of the most extensively studied reactions because it is relatively simple and includes all basic steps of a heterogeneous process, that is, adsorption, diffusion, dissociation, reaction and desorption [24]. In addition, it is also the most important part of the PROX reaction.

$\mathrm{Ru}$ has long been known as an exception in the Pt group metals, in terms of its behavior towards the oxidation of CO. Under UHV conditions, $\mathrm{Ru}$ is an extremely poor catalyst for oxidation of CO [25], yet its activity becomes greater than that of the other Pt group metals under high pressure and oxidizing conditions [26-28]. The reaction proceeds through the Langmuir-Hinshelwood (L-H) mechanism which requires the chemisorption of reactants before their recombination [28]. Stampfl

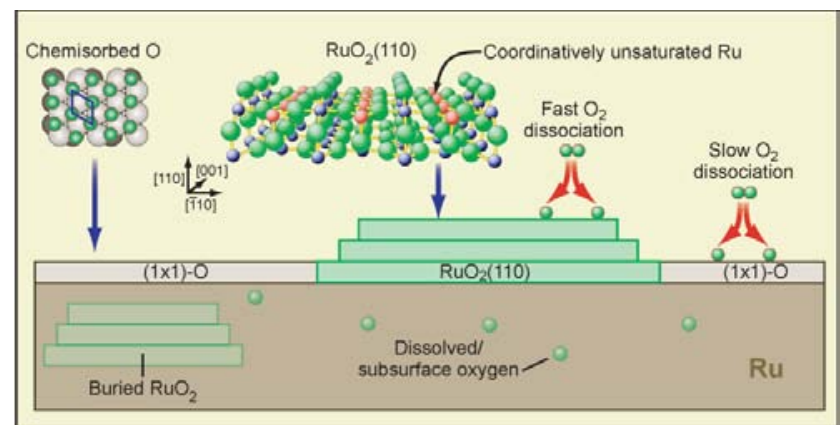

Fig. 3. The rich oxygen chemistry of ruthenium (0001). Reproduced with permission from Ref. [17]. Copyright 2002, the American Association for the Advancement of Science. 
et al. [29] found that formation of $(1 \times 1)-0$ overlayer on a $\mathrm{Ru}$ (0001) single crystal surface caused the material to become nearly inactive. It was proposed that the "pressure gap" can be bridged by forming $\mathrm{RuO}_{2}$ on $\mathrm{Ru}$ catalysts at elevated reactant pressures [21]. Over et al. [2] discussed the complex structure-activity correlation in $\mathrm{CO}$ oxidation on $\mathrm{Ru}$, based on results of in situ surface X-ray diffraction (SXRD) and on-line mass spectrometry measurements. They discovered that the activity of the catalyst increased when it underwent structural changes, either because it was reduced or because it formed $\mathrm{RuO}_{2}(110)$. According to density-functional theory (DFT) calculations (Fig. 4) reported by Over et al. [18], the cus (a coordinative unsaturated site) $\mathrm{Ru}$ atom has an exposed dangling bond at the surface, explaining the high reactivity of the $\mathrm{RuO}_{2}(110)$ surface. Gao et al. [30] expressed a different view that a chemisorbed oxygen surface is the most thermodynamically stable phase and active phase for CO oxidation. The core-shell structure with an ultrathin $\mathrm{RuO}_{2}$ shell coating a metallic $\mathrm{Ru}$ core - was identified as the most active and stable state. In contrast, Qadir et al. [31] showed that smaller $\mathrm{Ru}$ nanoparticles could form a huge bulk of $\mathrm{RuO}_{2}$ on their surfaces, leading to a lower catalytic activity. They reported that core-shell type $\mathrm{RuO}_{2}$ became more stable as the size of the nanoparticle increased.

\section{Gas-solid catalytic reactions}

\subsection{Catalytic oxidation of VOCs}

VOCs emitted from industrial processes and transportation activities are regarded as major contributors to air pollution and as dangerous to human health. Approaches for removal of VOCs include thermal incineration, catalytic oxidation and adsorption-based techniques. Because of advantages such as high efficiency, low temperature and high selectivity for harmless products, catalytic oxidation is considered a promising path-

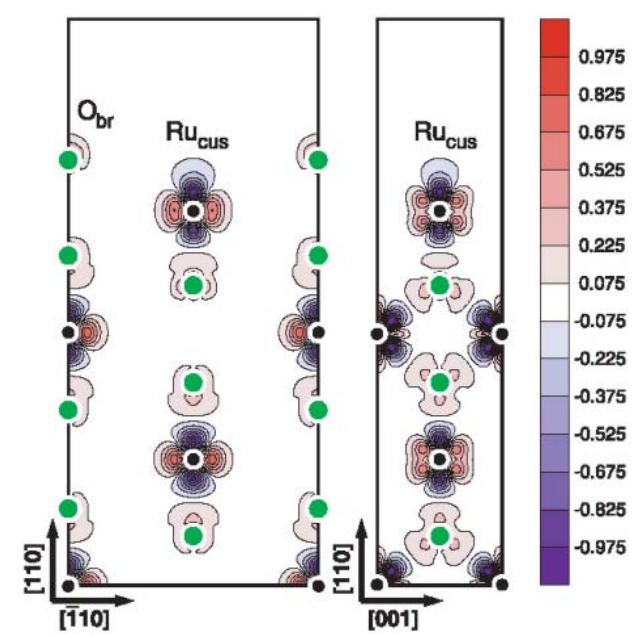

Fig. 4. Pseudovalence charge density contour plots of the $\mathrm{RuO}_{2}(110)$ surface cut through the cus-Ru atom along the [110] and the [001] directions from DFT calculations. Reproduced with permission from Ref. [18]. Copyright 2000, the American Association for the Advancement of Science. way to reduce VOCs emissions and meet the standards of air pollution control regulations.

Various catalysts, such as noble metals (Pt, $\mathrm{Pd}$, and $\mathrm{Au}$ ) [32-34] and transition metal oxides $\left(\mathrm{Co}_{3} \mathrm{O}_{4}, \mathrm{MnO}_{x}\right.$, and $\left.\mathrm{V}_{2} \mathrm{O}_{5}\right)$ [35-38], have been utilized for complete oxidation of VOCs. However, use of these catalysts often presents problems, including relatively low activity, rapid deactivation by chlorine poisoning or coking, high cost and formation of undesired polychlorinated benzenes. VOCs-oxidation catalyzed by Ru-based materials, compared with by other noble metals, has been much less studied. However, recently, Ru-promoted oxidation of VOCs was broadly reported because of its unique properties, with these reports summarized in Table 1.

Most recently, our group [39] prepared the Ru-based catalysts $\mathrm{Ru} / \mathrm{TiO}_{2}, \mathrm{Ru} / \mathrm{SiO}_{2}, \mathrm{Ru} / \gamma-\mathrm{Al}_{2} \mathrm{O}_{3}$ and $\mathrm{Ru} / \mathrm{ZrO}_{2}$ and evaluated their usefulness for $\mathrm{CH}_{3} \mathrm{Br}$ oxidation. We found that $\mathrm{Ru} / \mathrm{TiO}_{2}$ performed better catalytically than the other materials. By transmission electron microscopy (TEM) characterization, the $\mathrm{Ru}$ species were primarily distributed on the rutile phase of $\mathrm{P} 25 \mathrm{TiO}_{2} . \mathrm{Ru} / \mathrm{TiO}_{2}$ was also employed in the catalytic oxidation of CO, benzene, methyl acetate and multi-pollutants of a simulated PTA off-gas. Interestingly, when the temperature was below $200{ }^{\circ} \mathrm{C}$, all pollutants had conversions below $10 \%$, results far different from those of single-pollutant tests (Fig. 5). We tentatively propose that the oxygen-rich nature of methyl acetate was the key factor in its being oxidized far more rapidly when in competition with other compounds on the catalyst surface.

Using different types of $\mathrm{TiO}_{2}$ (anatase, P25 and rutile) as supports, our group [40] synthesized supported-Ru catalysts with homogeneously distributed $\mathrm{Ru}$ particles via wet impregnation. All of these catalysts were very active for trichloroethylene oxidation, but we found that $\mathrm{Ru}$ oxide species formed during the reaction were very unstable in the anatase phase of $\mathrm{TiO}_{2}$. In the presence of the rutile phase of $\mathrm{TiO}_{2}$, which had a similar structure to that of $\mathrm{RuO}_{2}$, the $\mathrm{Ru}$ species tended to distribute on the rutile $\mathrm{TiO}_{2}$. The $\mathrm{Ru} / \mathrm{P} 25$ catalyst, with a larger

Table 1

Catalytic oxidation of VOCs over Ru-based catalysts, as reported in recent literature.

\begin{tabular}{lcrr}
\hline Catalyst & VOCs (Concentration) & $\begin{array}{c}\text { Conversion } \\
\text { of VOCs (\%) } \\
\left(T /{ }^{\circ} \mathrm{C}\right)\end{array}$ & Ref. \\
\hline $1 \% \mathrm{Ru} / \mathrm{TiO}_{2}(\mathrm{P} 25)$ & Methyl bromide $(100 \mathrm{ppm})$ & $90(212)$ & {$[39]$} \\
$1 \% \mathrm{Ru} / \mathrm{TiO}_{2}(\mathrm{P} 25)$ & Trichloroethylene $(500 \mathrm{ppm})$ & $90(249)$ & {$[40]$} \\
$1 \% \mathrm{Ru} / \mathrm{Co}_{3} \mathrm{O}_{4}-\mathrm{MOF}$ & Toluene $(1000 \mathrm{ppm})$ & $90(238)$ & {$[41]$} \\
$0.38 \% \mathrm{Ru} / \mathrm{CeO}_{2}$ & Chlorobenzene $(1000 \mathrm{ppm})$ & $90(280)$ & {$[42]$} \\
$1 \% \mathrm{Ru}-\mathrm{CeO}_{2}$ & Chlorobenzene $(550 \mathrm{ppm})$ & $90(240)$ & {$[43]$} \\
$1 \% \mathrm{Ru} / \mathrm{Ti}^{-}-\mathrm{CeO}_{2}$ & Chlorobenzene $(550 \mathrm{ppm})$ & $90(210)$ & {$[44]$} \\
$4.9 \% \mathrm{Ru} / \gamma-\mathrm{Al}_{2} \mathrm{O}_{3}$ & Propane $(2000 \mathrm{ppm})$ & $95(195)$ & {$[45]$} \\
$4.5 \% \mathrm{Ru} / \mathrm{ZnAl}_{2} \mathrm{O}_{4}$ & Propane $(2000 \mathrm{ppm})$ & $50(198)$ & {$[46]$} \\
$4.6 \% \mathrm{Ru} / \gamma-\mathrm{Al}_{2} \mathrm{O}_{3}$ & Butane $(2000 \mathrm{ppm})$ & $100(190)$ & {$[47]$} \\
$1 \% \mathrm{Ru} / \mathrm{CeO}{ }_{2}$ & Ethyl acetate $(1000 \mathrm{ppm})$ & $90(190)$ & {$[48]$} \\
$4.6 \% \mathrm{Ru} / \gamma-\mathrm{Al}_{2} \mathrm{O}_{3}$ & Propane $(2000 \mathrm{ppm})$ & $50(175)$ & {$[49]$} \\
$1 \% \mathrm{Ru} / \mathrm{CeO} \mathrm{C}_{2}$ & Propylene $(6000 \mathrm{ppm})$ & $50(177)$ & {$[52]$} \\
$0.5 \% \mathrm{Ru} / \mathrm{Al}_{2} \mathrm{O}_{3}$ & Trichloroethylene $(1091 \mathrm{ppm})$ & $50(326)$ & {$[53]$} \\
$5 \% \mathrm{RuO}{ }_{2} / \mathrm{CeO}_{2}$ & Propylene $(4000 \mathrm{ppm})$ & $100(423)$ & {$[54]$} \\
\hline
\end{tabular}



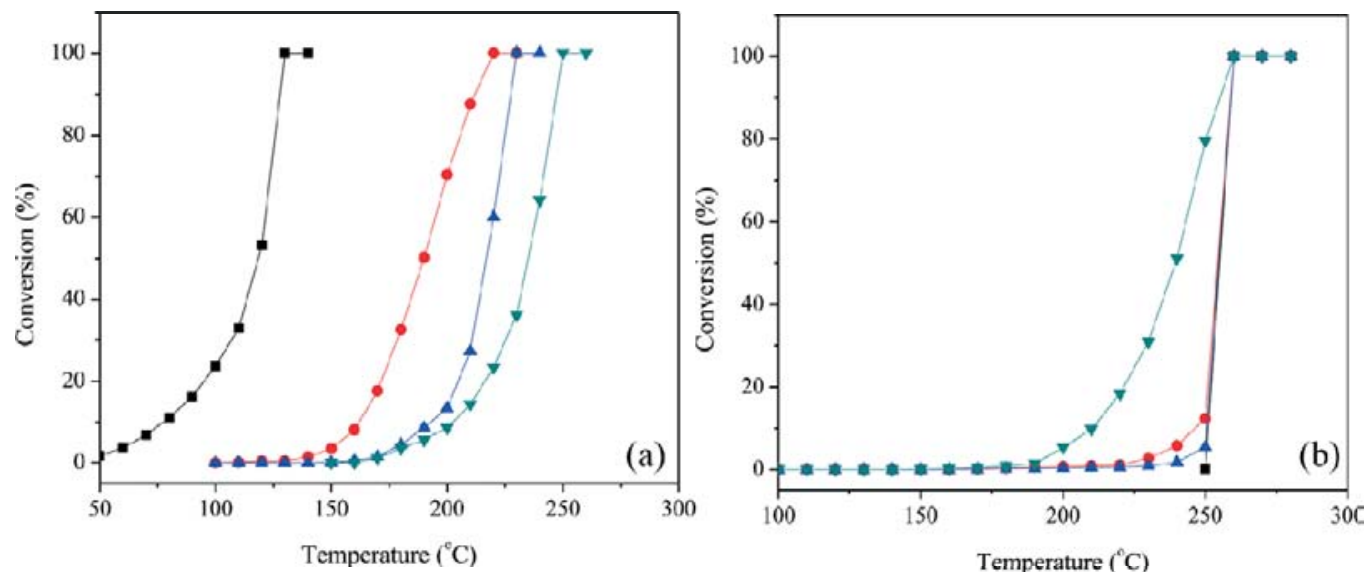

Fig. 5. (a) Single-pollutant test: $\mathrm{CO}(\boldsymbol{\bullet}), \mathrm{CH}_{3} \mathrm{Br}(\bullet)$, benzene $(\boldsymbol{\Lambda})$ and methyl acetate $(\boldsymbol{\nabla})$ conversions over $\mathrm{Ru} / \mathrm{TiO}_{2}$ as a function of reaction temperature; (b) Multi-pollutant test: $\mathrm{CO}(\boldsymbol{\bullet}), \mathrm{CH}_{3} \mathrm{Br}(\bullet)$, benzene $(\boldsymbol{\Delta})$ and methyl acetate $(\boldsymbol{\nabla})$ conversions over $\mathrm{Ru} / \mathrm{TiO}_{2}$ as a function of reaction temperature. Experiments were performed under the following conditions: pollutant concentrations $=3500,100,200$ and 500 ppm, respectively; $\mathrm{O}_{2}$ concentration $=20 \mathrm{vol} \%$ and WHSV $=60000 \mathrm{~mL} \mathrm{~g}^{-1} \mathrm{~h}^{-1}$. Reproduced with permission from Ref. [39]. Copyright 2016, Royal Society of Chemistry.

particle size, showed apparently better catalytic performance than the other two samples. This was tentatively attributed to a size effect, which has been well demonstrated in Pt catalytic systems. The existence of additional water vapor greatly increased $\mathrm{HCl}$ formation and reduced the amount of tetrachloroethylene and pentachloroethane as the organic byproducts, whereby catalytic activity was also suppressed, as shown in Fig 6.

Our group [41] reported $\mathrm{Ru} / \mathrm{Co}_{3} \mathrm{O}_{4}$-metal-organic frame-
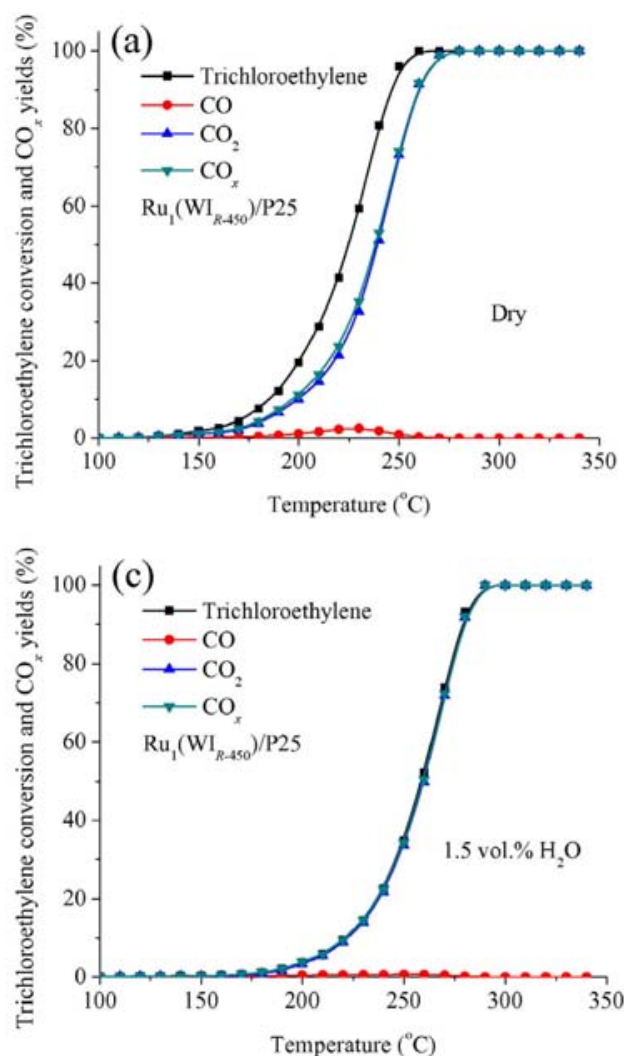

work (MOF)- catalyzed toluene oxidation. In the preparation, the $\mathrm{Co}_{3} \mathrm{O}_{4}$-MOF support was synthesized through a template method for MOF-synthesis and the catalyst was then obtained by the impregnation method. For comparison, the $\mathrm{Ru} / \mathrm{Co}_{3} \mathrm{O}_{4}-\mathrm{B}$ catalyst was also prepared by the traditional precipitation-impregnation method. We showed that $\mathrm{Ru} / \mathrm{Co}_{3} \mathrm{O}_{4}-\mathrm{MOF}$ exhibited far better catalytic activity, $\mathrm{CO}_{2}$ selectivity, stability and anti-moisture properties than other materials. BET, XRD and XPS characterization revealed that $\mathrm{Ru} / \mathrm{Co}_{3} \mathrm{O}_{4}-\mathrm{MOF}$ had a
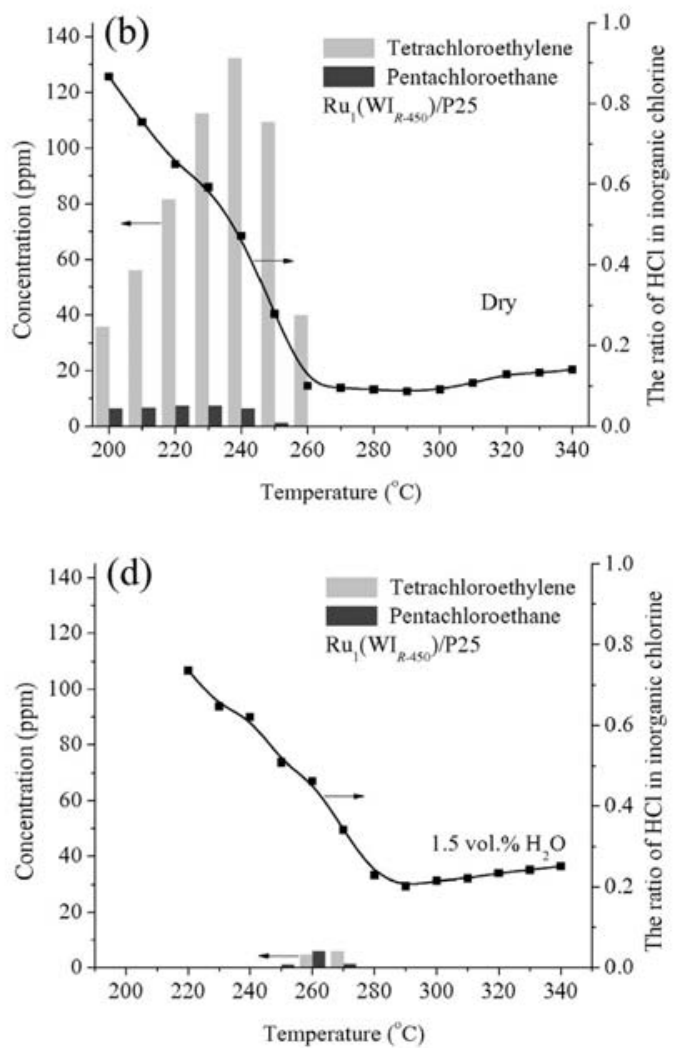

Fig. 6. Trichloroethylene conversion and $\mathrm{CO}_{x}$ yields $(\mathrm{a}, \mathrm{c})$, distribution of the organic byproducts and fraction of $\mathrm{HCl}$ in inorganic chlorine $(\mathrm{b}, \mathrm{d})$ as a function of temperature over the $\mathrm{Ru}_{1}\left(\mathrm{WI}_{\mathrm{R}-450}\right) / \mathrm{P} 25$ catalyst in the absence $(\mathrm{a}, \mathrm{b})$ and presence $(\mathrm{c}, \mathrm{d})$ of additional water vapor. Reproduced with permission from Ref. [40]. Copyright 2016, Elsevier. 


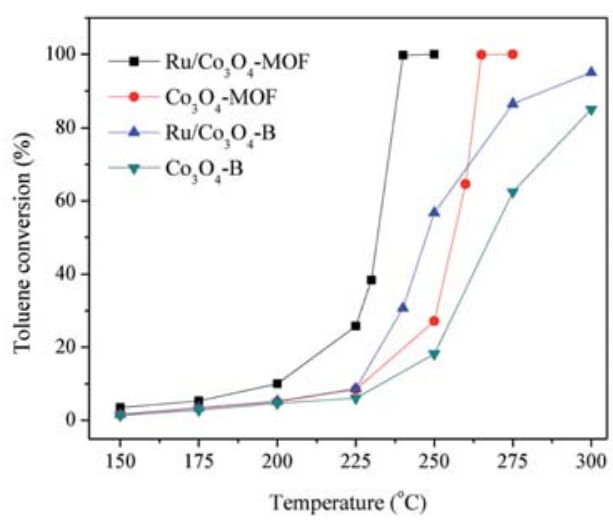

Fig. 7. Toluene conversion as a function of reaction temperature over the catalysts. Reproduced with permission from Ref. [41]. Copyright 2015, Royal Society of Chemistry.

larger surface area than $\mathrm{Ru} / \mathrm{Co}_{3} \mathrm{O}_{4}-\mathrm{B}$, and that $\mathrm{Ru}$ species were well dispersed on the surface of $\mathrm{Ru} / \mathrm{Co}_{3} \mathrm{O}_{4}$-MOF (Fig. 7).

Huang et al. [42] loaded $\mathrm{Ru}$ on $\mathrm{CeO}_{2}$ with different morphological structures, such as nanorods, nanocubes and nanoocto. Their characterization studies revealed that $\mathrm{Ru} / \mathrm{CeO}_{2}-\mathrm{r}$ exhibited the most abundant $\mathrm{Ru}^{4+}$, oxygen vacancies and $\mathrm{Ru}-\mathrm{O}-\mathrm{Ce}$ bonds. The investigators concluded that a strong interaction existed between $\mathrm{Ru}$ and the $\mathrm{CeO}_{2}-\mathrm{r}$ support. Indeed, chlorobenzene oxidation tests showed that $\mathrm{Ru} / \mathrm{CeO}_{2}-\mathrm{r}$ gave the highest catalytic activity, demonstrating that the activity of $\mathrm{Ru} / \mathrm{CeO}_{2}$ for chlorobenzene was greatly influenced by the shape/crystal plane (Fig. 8).

Dai et al. [43] studied the mechanism of CB oxidation over $\mathrm{Ru} / \mathrm{CeO}_{2}$ catalysts and proposed that the $\mathrm{C}-\mathrm{Cl}$ cleavage would first occur at the $\mathrm{Ce}^{3+} / \mathrm{Ce}^{4+}$ active sites, forming $\mathrm{Cl}_{2}$ through the

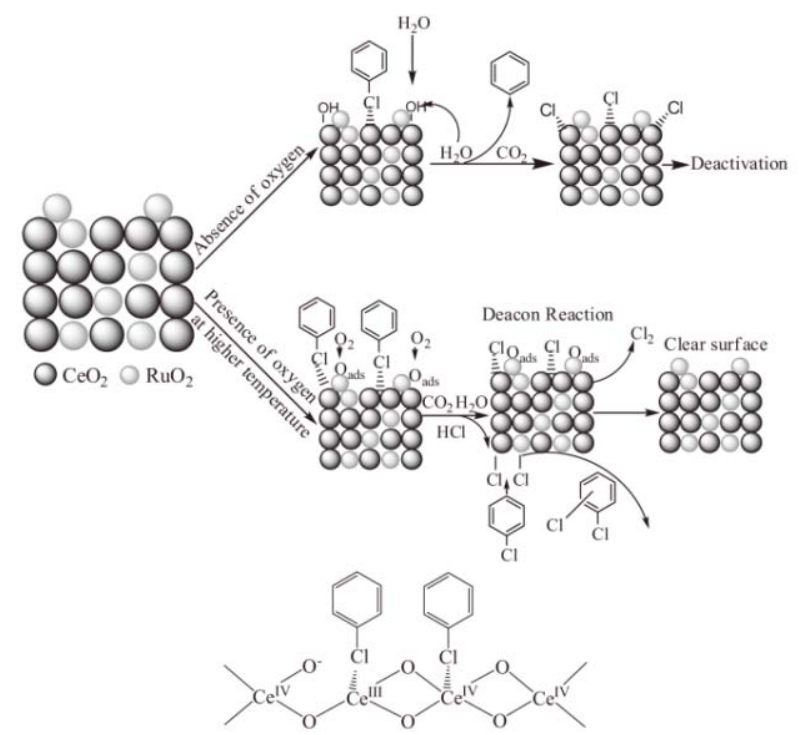

Fig. 9. Proposed reaction mechanism for catalytic oxidation of $\mathrm{CB}$ over $\mathrm{Ru} / \mathrm{CeO}_{2}$ catalyst. Reproduced with permission from Ref. [43]. Copyright 2012, Elsevier.

Deacon process. The partial $\mathrm{C}$ and $\mathrm{H}$ of the intermediates would then be oxidized into $\mathrm{CO}_{2}$ and $\mathrm{H}_{2} \mathrm{O}$ by the active oxygen and lattice oxygen on the catalyst surface and the $\mathrm{Cl}_{2}$ would finally be adsorbed on the active sites, leading to deactivation of the catalyst (Fig. 9).

In their next study, Dai et al. [44] doped $\mathrm{TiO}_{2}$ into $1 \% \mathrm{Ru} / \mathrm{CeO}_{2}$ to obtain $1 \% \mathrm{Ru} / \mathrm{Ti}-\mathrm{CeO}_{2}$, reporting an increased activity of this catalyst for $\mathrm{CB}$ oxidation. They further reported that $1 \% \mathrm{Ru} / 5 \% \mathrm{Ti}-\mathrm{CeO}_{2}$ showed the highest activity. $\mathrm{H}_{2}$-TPR and TEM results showed that $1 \% \mathrm{Ru} / \mathrm{Ti}-\mathrm{CeO}_{2}$ exhibited great re-
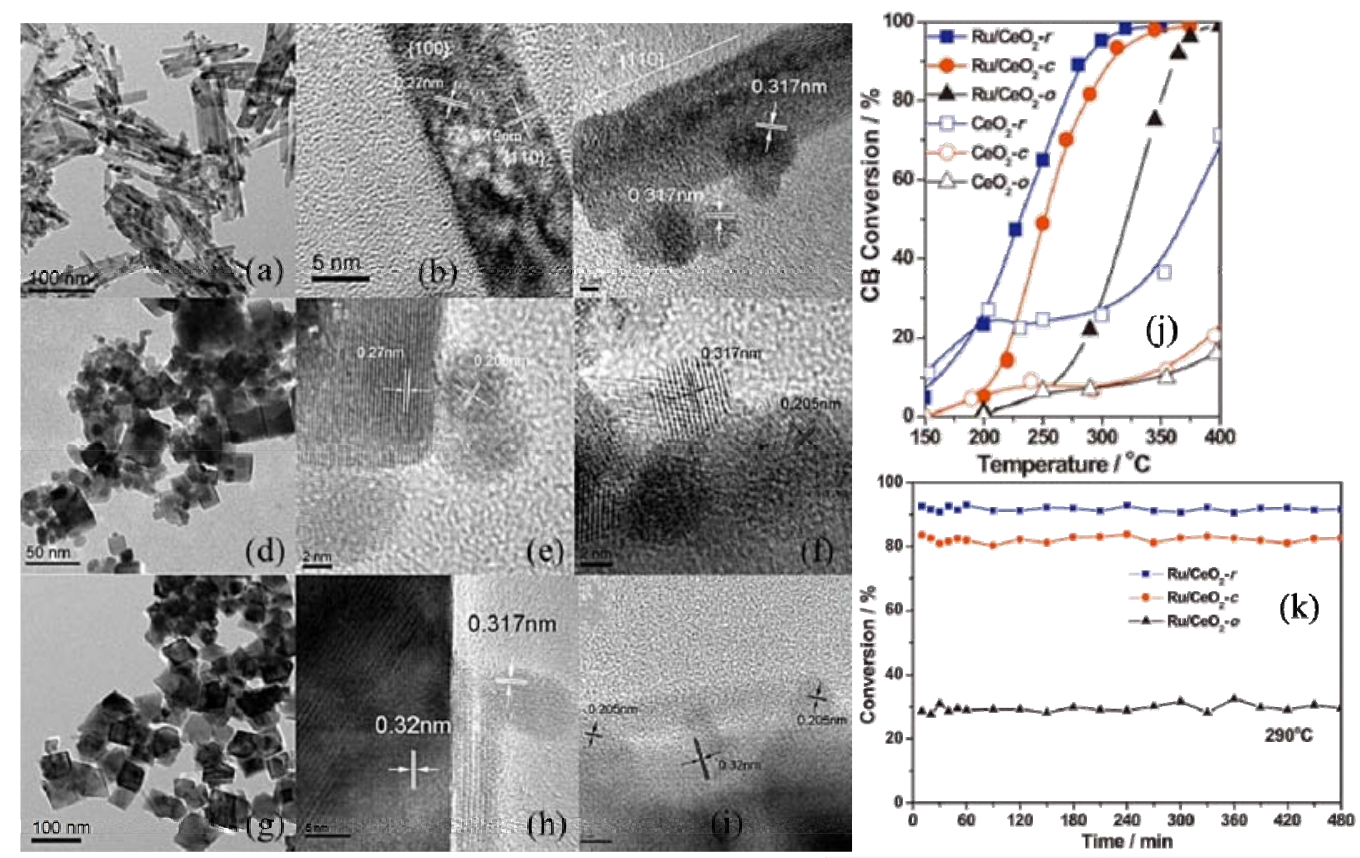

Fig. 8. (a-c) TEM and HRTEM images of $\mathrm{Ru} / \mathrm{CeO}_{2}-\mathrm{r}$; (d-f) TEM and HRTEM images of $\mathrm{Ru} / \mathrm{CeO}_{2}-\mathrm{c}$; (g-i) TEM and $\mathrm{HRTEM}$ images of Ru/CeO ${ }_{2}-\mathrm{o}$; (j) Conversion of chlorobenzene (CB) over various $\mathrm{CeO}_{2}$ and $\mathrm{Ru} / \mathrm{CeO}_{2}$ catalysts; (k) Stability of different $\mathrm{Ru} / \mathrm{CeO}_{2}$ catalysts at $290^{\circ} \mathrm{C}$. Reproduced with permission from Ref. [42]. Copyright 2014, Elsevier. 
ducibility at low temperatures because of its active oxygen-rich nature and that the strengthened interaction between $\mathrm{Ru}$ and $\mathrm{CeO}_{2}$ was an oxidation, ascribed to the high-energy lattice planes of $\mathrm{CeO}_{2}$ (110) and (100). Okal et al. [45] employed $4.9 \% \mathrm{Ru} / \gamma-\mathrm{Al}_{2} \mathrm{O}_{3}$ and $\mathrm{H}_{2}$-reduced catalyst in propane. The $T_{95}$ values of the former and latter catalysts were 195 and $205{ }^{\circ} \mathrm{C}$, respectively. By TEM characterization, the former exhibited $\mathrm{Ru}$ particles with an average size of $1.6 \mathrm{~nm}$, whereas those in the latter had an average size of $6.0 \mathrm{~nm}$. In another study, Okal et al. [46] prepared $\mathrm{Ru} / \mathrm{ZnAl}_{2} \mathrm{O}_{4}$ catalysts with different $\mathrm{Ru}$ contents $(0.5 \%, 1 \%$, and $4.5 \%)$, and employed these catalysts for propane oxidation. The $4.5 \% \mathrm{Ru} / \mathrm{ZnAl}_{2} \mathrm{O}_{4}$ showed the highest catalytic efficiency. XRD and HRTEM/SAED results revealed that the $\mathrm{Ru}$ species had a small particle size and these were well dispersed on $\mathrm{ZnAl}_{2} \mathrm{O}_{4}$. The decreased $\mathrm{ZnAl}_{2} \mathrm{O}_{4}$ particle size facilitated the catalytic efficiency. Mitsui et al. [48] compared the catalytic performance of $\mathrm{CeO}_{2}$-supported noble metals, such as $\mathrm{Ru}, \mathrm{Pt}, \mathrm{Pd}$ and $\mathrm{Rh}$, in the oxidation of ethyl acetate and found that the Ru-containing catalyst demonstrated the highest catalytic activity with a $T_{90}=190{ }^{\circ} \mathrm{C}$. Okal et al. [49] reported the preparation of washed $4.6 \% \mathrm{Ru} / \gamma-\mathrm{Al}_{2} \mathrm{O}_{3}$ and their XPS spectra revealed a very low chlorine content. Catalytic oxidation of propane over unwashed and washed catalysts gave $T_{50}=315$ and $175{ }^{\circ} \mathrm{C}$, respectively. It was proposed that chlorine extensively occupied the active sites on the catalyst surface [50,51]. Aouad et al. [52] prepared $\mathrm{Ru} / \mathrm{CeO}_{2}$ with different $\mathrm{Ru}$ contents of $(0.67 \%, 1 \%, 3 \%$ and $5 \%)$. Based on catalytic oxidation of propene, the catalytic efficiency was slightly changed when the $\mathrm{Ru}$ content was above $1 \%$. Based on TPR results, the Ru species were saturated on the catalyst surface for $1 \% \mathrm{Ru} / \mathrm{CeO}_{2}$. Miranda et al. [53] employed $0.5 \% \mathrm{Ru} / \mathrm{Al}_{2} \mathrm{O}_{3}$ for trichloroethene oxidation. Compared with the blank test, they found that $T_{50}$ was decreased from 700 to $326^{\circ} \mathrm{C}$. Hosokawa et al. [54] loaded Ru on different supports $\left(\mathrm{CeO}_{2}, \gamma-\mathrm{Al}_{2} \mathrm{O}_{3}\right.$, and $\left.\mathrm{ZrO}_{2}\right)$ and employed these for propene oxidation. $\mathrm{RuO}_{2} / \mathrm{CeO}_{2}$ exhibited the highest catalytic activity, with $T_{100}=423{ }^{\circ} \mathrm{C}$, and it was proposed that propene molecules were easily influenced by $\mathrm{Ru}=0$.

Currently available studies were primarily focused on the catalytic oxidation of single VOC pollutant and catalytic evaluation and stability test were commonly reported. The detailed oxidation process has been explored far less frequently, though this would inform catalyst development. In addition, reaction conditions closer to those involving real waste gas should be employed in such studies. Hence, mechanistic and kinetic studies and catalytic oxidation of VOCs with multi-pollutants should be strongly encouraged for inclusion in future research.

\subsection{Preferential oxidation of CO (PROX)}

In recent years, hydrogen-polymer electrolyte membrane fuel cells ( $\mathrm{H}_{2}$-PEMFC) have attracted increasing interest as an environmentally compatible supply of electric energy $[55,56]$. In these fuel processors, hydrocarbons are transformed into $\mathrm{H}_{2}$. PROX is an essential step in the fuel processing system for a low temperature $\mathrm{H}_{2}$-PEMFC and is employed to remove residual $\mathrm{CO}$ from an $\mathrm{H}_{2}$-rich stream. This is done because $\mathrm{CO}$ can degrade the electrochemical performance of the PEMFC.
In the PROX system, $\mathrm{CO}$ oxidation (Eq. (1)), $\mathrm{H}_{2}$ oxidation (Eq. (2)), $\mathrm{CO}$ methanation (Eq. (3)), $\mathrm{CO}_{2}$ methanation (Eq. (4)) and the water-gas shift reaction may occur concurrently because all of the reactants $\left(\mathrm{CO}, \mathrm{CO}_{2}, \mathrm{H}_{2}, \mathrm{O}_{2}\right.$, and $\left.\mathrm{H}_{2} \mathrm{O}\right)$ coexist in the system. Consequently, undesired reactions, such as $\mathrm{H}_{2}$ oxidation, $\mathrm{CO}$ methanation and $\mathrm{CO}_{2}$ methanation, must be minimized during PROX. For practical applications, PROX catalysts should have a wide temperature window and be able to perform under low temperatures to facilitate complete $\mathrm{CO}$ removal. Thus, we concluded that the Ru-based catalysts are suitable for PROX systems, based on recent reports using these agents, as summarized in Table 2 .

$$
\begin{aligned}
\mathrm{CO}+(1 / 2) \mathrm{O}_{2} & \rightarrow \mathrm{CO}_{2} \\
\mathrm{H}_{2}+(1 / 2) \mathrm{O}_{2} & \rightarrow \mathrm{H}_{2} \mathrm{O} \\
\mathrm{CO}+3 \mathrm{H}_{2} & \rightarrow \mathrm{CH}_{4}+\mathrm{H}_{2} \mathrm{O} \\
\mathrm{CO}_{2}+4 \mathrm{H}_{2} & \rightarrow \mathrm{CH}_{4}+2 \mathrm{H}_{2} \mathrm{O}
\end{aligned}
$$

Kim et al. [57] obtained $\mathrm{SiO}_{2}$ with different surface areas by varying the calcination temperatures for supports and the $\mathrm{Ru} / \mathrm{SiO}_{2}$ catalysts were synthesized through the incipient-wetness impregnation method. These investigators observed that the surface area decreased with increased calcination temperature and the $\mathrm{Ru}$ particle size increased with decreased surface area. When the calcination temperature for support was $830{ }^{\circ} \mathrm{C}$, the $\mathrm{Ru} / \mathrm{SiO}_{2}$ was more effective than other materials. In another study [58], a series of Ru-based catalysts, $\mathrm{Ru} \mathrm{Ru} / x-\mathrm{Al}_{2} \mathrm{O}_{3}(x=\alpha, \kappa, \gamma, \eta, \delta$, and $\theta)$, were employed in PROX. $\mathrm{Ru} / \alpha-\mathrm{Al}_{2} \mathrm{O}_{3}$ was the most efficient catalyst, with an average $\mathrm{Ru}$ particle size of $2.6 \mathrm{~nm}$ and well dispersed Ru particles on the catalyst. $\mathrm{H}_{2}$-TPR experiments for $\mathrm{Ru} / \alpha-\mathrm{Al}_{2} \mathrm{O}_{3}$ showed that $\mathrm{Ru}$ species could be reduced at a low temperature of $100{ }^{\circ} \mathrm{C}$. Kim et al. [59] loaded Ru on different supports (yttria-stabilized zirconia (YSZ), $\mathrm{ZrO}_{2}, \mathrm{TiO}_{2}, \mathrm{SiO}_{2}, \gamma-\mathrm{Al}_{2} \mathrm{O}_{3}$ ) via wetness-impregnation. In the PROX reaction, Ru/YSZ showed an apparently higher catalytic activity than other materials. On TEM images, Ru species were well dispersed on the YSZ support and the average $\mathrm{Ru}$ particle size was $1.2 \mathrm{~nm}$. The outlet $\mathrm{CO}$ concentration was below 10 ppm, even when $\mathrm{CO}_{2}$ (17.4 vol\%) and $\mathrm{H}_{2} \mathrm{O}(13.0$ vol\%) were introduced. Kim et al. [60] examined $\gamma-\mathrm{Al}_{2} \mathrm{O}_{3}$-supported noble metal catalysts in which the metal content was ( $5 \%$ or $0.5 \%$ ), at different reaction temperatures, as shown in Fig. 10. They found that the catalytic activity of $5 \% \mathrm{Ru} / \gamma-\mathrm{Al}_{2} \mathrm{O}_{3}$ was the highest, compared with those of other catalysts. In the absence of $\mathrm{H}_{2} \mathrm{O}$ and $\mathrm{CO}_{2}, 100 \%$ CO conversion could be achieved over $5 \% \mathrm{Ru} / \gamma-\mathrm{Al}_{2} \mathrm{O}_{3}$ over a wide range of reaction

Table 2

PROX over Ru-based catalysts, as reported in recent literature.

\begin{tabular}{lcccc}
\hline Catalyst & $\begin{array}{c}\mathrm{CO} \text { concentration } \\
(\text { vol\%) }\end{array}$ & $\begin{array}{c}\text { Conversion } \\
\text { of } \mathrm{CO}(\%)\end{array}$ & $T /{ }^{\circ} \mathrm{C}$ & Ref. \\
\hline $1.08 \% \mathrm{Ru} / \mathrm{SiO}_{2}$ & 1 & 95 & 400 & {$[57]$} \\
$0.696 \% \mathrm{Ru} / \alpha-\mathrm{Al}_{2} \mathrm{O}_{3}$ & 1 & 98 & 390 & {$[58]$} \\
$0.64 \% \mathrm{Ru} / \mathrm{YSZ}$ & 1 & 80 & 380 & {$[59]$} \\
$5.0 \% \mathrm{Ru} / \gamma-\mathrm{Al}_{2} \mathrm{O}_{3}$ & 1 & 100 & 333 & {$[60]$} \\
$3.8 \% \mathrm{Ru} / \mathrm{Al}_{2} \mathrm{O}_{3}$ & 0.3 & 99.8 & 150 & {$[61]$} \\
$1.0 \% \mathrm{Ru} / \theta-\mathrm{Al}_{2} \mathrm{O}_{3}$ & 0.5 & 99 & 140 & {$[62]$} \\
$5.0 \% \mathrm{Ru} / \mathrm{ZrO}_{2}$ & 1 & 96 & 310 & {$[63]$} \\
$5.0 \% \mathrm{Ru} / \gamma-\mathrm{Al}_{2} \mathrm{O}_{3}$ & 1 & 96 & 75 & {$[64]$} \\
\hline
\end{tabular}



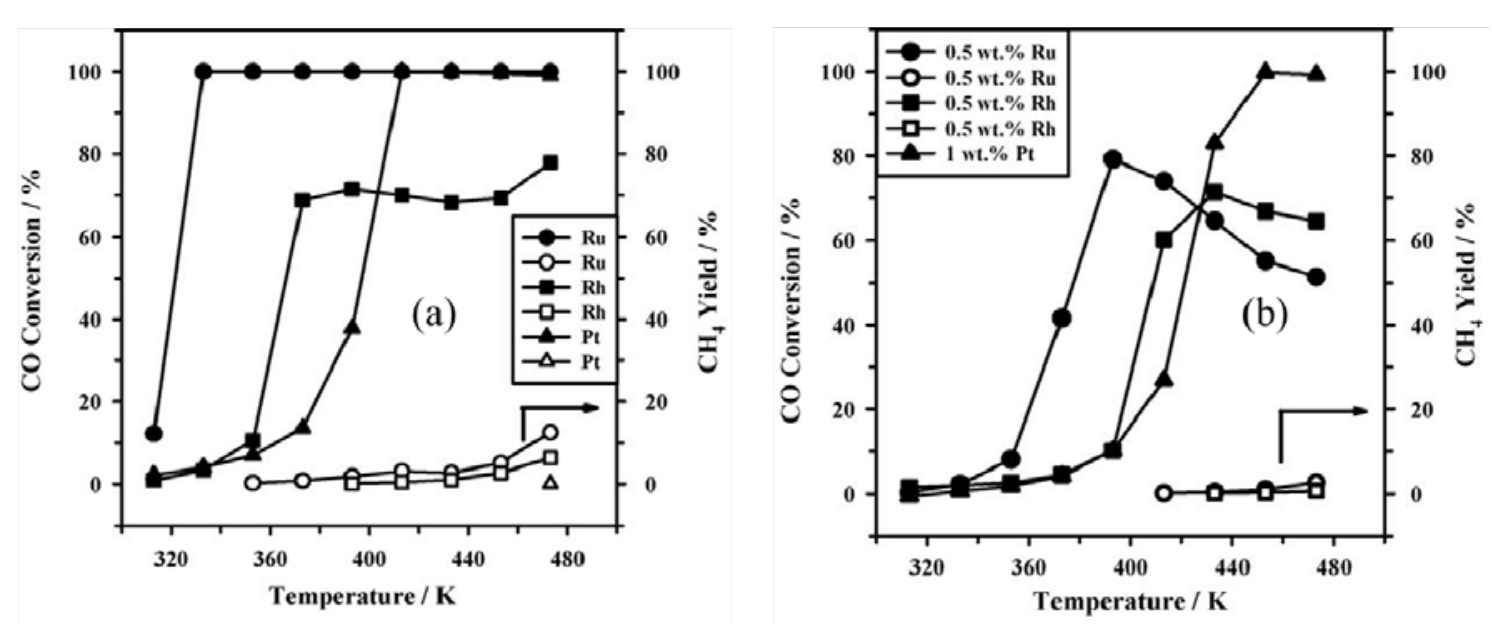

Fig. 10. (a) Temperature-dependence of $\mathrm{CO}$ conversion and $\mathrm{CH}_{4}$ yield for PROX over $5 \%$ noble metal catalysts supported on $\gamma$ - $\mathrm{Al}_{2} \mathrm{O}_{3}$; (b) $\mathrm{CO}$ conversion and $\mathrm{CH}_{4}$ yield for PROX over $0.5 \%$ noble metal catalysts supported on $\gamma-\mathrm{Al}_{2} \mathrm{O}_{3}$ with increasing temperature. All catalysts were reduced in $\mathrm{H}_{2}$ at $300^{\circ} \mathrm{C}$ before the reaction. Reproduced with permission from Ref. [60]. Copyright 2009, Elsevier.

temperatures, from 60 to $200{ }^{\circ} \mathrm{C}$. Though $0.5 \mathrm{wt} \% \mathrm{Ru} / \gamma-\mathrm{Al}_{2} \mathrm{O}_{3}$ and $5 \mathrm{wt} \% \mathrm{Ru} / \gamma-\mathrm{Al}_{2} \mathrm{O}_{3}$ had similar particle size distributions by TEM analysis, the latter catalyst, with a smaller amount of chemisorbed $\mathrm{CO}$ and $\mathrm{O}_{2}$ per $\mathrm{Ru}$ atom, showed much better PROX activity.

Hidenobu et al. [61] studied the influence of $\mathrm{NH}_{3}$ on $\mathrm{Ru} / \mathrm{Al}_{2} \mathrm{O}_{3}$-catalyzed selective $\mathrm{CO}$ oxidation and found that the catalyst showed lower activity in the presence of $\mathrm{NH}_{3}$ at a high ratio of $\left[\mathrm{O}_{2}\right] /[\mathrm{CO}]$. It was suggested that high $\mathrm{O}_{2}$-concentration facilitated oxidation of $\mathrm{NH}_{3}$ and generation of nitrosyl, which led to the deactivation of the catalyst. Similarly, the presence of $\mathrm{NO}$ or $\mathrm{NO}_{2}$ also resulted in nitrosyl-induced deactivation (Fig. 11). Chin et al. [62] examined the influence of $\mathrm{Ru}$ precursors, $\mathrm{H}_{2} \mathrm{O}$ and $\mathrm{CO}_{2}$ on the $\mathrm{Ru} / \mathrm{Al}_{2} \mathrm{O}_{3}$-catalyzed PROX reaction. The

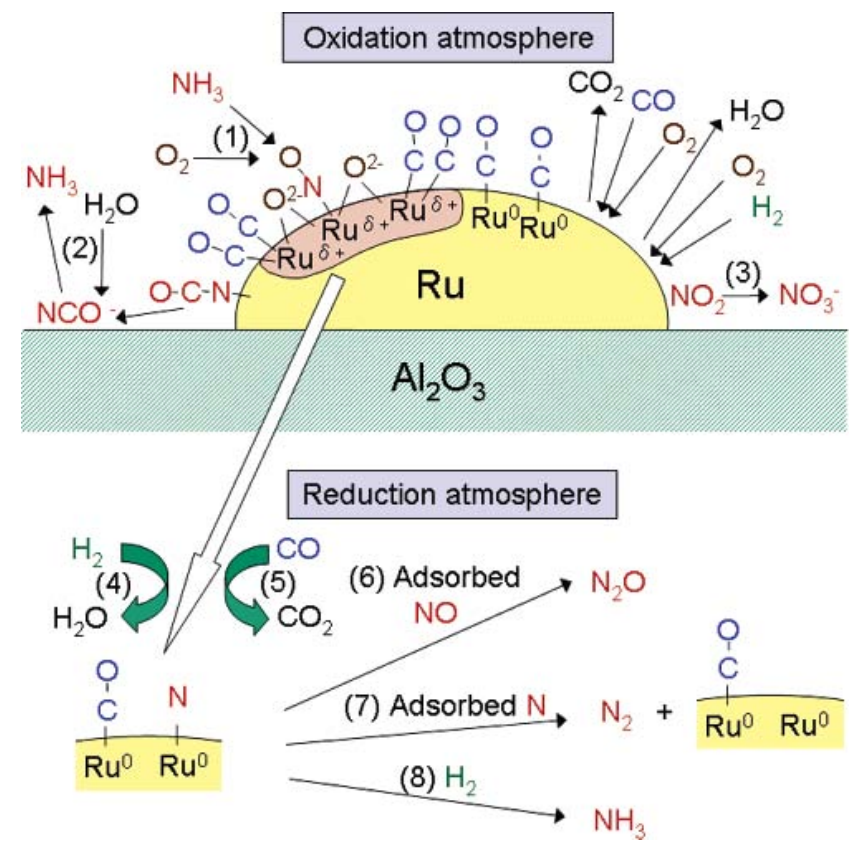

Fig. 11. Deactivation and reactivation models over a $\mathrm{Ru} / \mathrm{Al}_{2} \mathrm{O}_{3}$ catalyst. Reproduced with permission from Ref. [61]. Copyright 2007, American Chemical Society. activity of the catalyst made from nitrate precursors $\left(\mathrm{Ru}(\mathrm{NO})\left(\mathrm{NO}_{3}\right)_{3} \cdot x \mathrm{H}_{2} \mathrm{O}\right)$ was apparently higher than those made from chloride hydroxyl precursors $\left(\mathrm{RuCl}_{3} \cdot x \mathrm{H}_{2} \mathrm{O}, \mathrm{Ru}_{3}(\mathrm{CO})_{12}\right)$. $99 \%$ CO conversion was achieved at $140{ }^{\circ} \mathrm{C}$ with the catalyst using $\mathrm{Ru}(\mathrm{NO})\left(\mathrm{NO}_{3}\right)_{3} \cdot \mathrm{H}_{2} \mathrm{O}$ as a precursor. The high turnover frequency (TOF) was ascribed to the homogeneous dispersal of $\mathrm{Ru}$ species, as seen from HRTEM images. The introduction of $10 \% \mathrm{H}_{2} \mathrm{O}$ had a significant inhibitory effect when the reaction temperature was below $180{ }^{\circ} \mathrm{C}$ and a promotional effect was demonstrated clearly when the temperature was above $200{ }^{\circ} \mathrm{C}$. Moreover, $15 \% \mathrm{CO}_{2}$ severely inhibited $\mathrm{CO}$ oxidation. Han et al. [64] employed $\mathrm{Ru} / \gamma-\mathrm{Al}_{2} \mathrm{O}_{3}$ to remove $\mathrm{CO}$ from fuel gas and the CO conversion reached $96 \%$ at $75^{\circ} \mathrm{C}$. In this study, TEM images showed a Ru particle size of $2.5 \mathrm{~nm}$.

Simply stated, the key to the application of PROX is to develop a highly active and selective catalyst that could be employed over a wide temperature range and that exhibits good resistance to $\mathrm{CO}_{2}$ and $\mathrm{H}_{2} \mathrm{O}$. Introduction of the second transition metal component to form a bimetallic catalyst [6] or core-shell structure [31] may be a useful approach to enhance low temperature activity for PROX.

\subsection{Ammonia synthesis}

Ammonia and its processed products play significant roles in the pharmaceutical, metallurgy and environmental protection industries. However, ammonia synthesis is highly energy consuming. The primary difficulty in ammonia synthesis originates from the character of the $\mathrm{N} \equiv \mathrm{N}$ bond, which is the strongest bond among diatomic molecules. The role of the catalyst is to lower the dissociation energy of the $\mathrm{N} \equiv \mathrm{N}$ bond [65]. To decrease the energy required for this reaction, significant effort has focused on the search for efficient catalysts for ammonia synthesis at low temperature and low pressure.

Iron (Fe)-based materials are well established as first-generation ammonia synthesis catalysts. Yet, the requirements of high temperature and pressure directly lead to high costs and energy consumption. In the seventies, Aika et al. [66] found that 
$\mathrm{Ru}-\mathrm{K} / \mathrm{AC}$ was very efficient for ammonia synthesis, 10 times more than was the Fe-based catalyst at $250^{\circ} \mathrm{C}$, under ordinary pressure. This report received considerable attention from researchers worldwide. Compared with the traditional Fe catalyst, the supported-Ru catalyst was more reactive at lower temperatures under lower pressures $[67,68]$. Additionally, the $\mathrm{Ru}$ catalyst is insensitive to $\mathrm{H}_{2} \mathrm{O}, \mathrm{CO}_{x}$ and $\mathrm{NH}_{3}$ concentrations and, thus, is regarded as the ideal second-generation ammonia synthesis catalyst. Many studies proved that the catalytic performance of Ru-based catalysts for ammonia synthesis depended on the nature of the supports. It was proposed that strong interactions between $\mathrm{Ru}$ and the support led to rapid electron transfer from the support to Ru particle surface. Doping of other elements might provide more oxygen vacancies and effectively prevent catalyst agglomeration from high temperatures calcination. The results of recent studies on Ru-catalyzed ammonia synthesis are summarized in Table 3.

Wang et al. [69] prepared $\mathrm{Ru} / \mathrm{BaTiO}_{3}$ with the impregnation method and observed that the catalyst exhibited higher efficiency for ammonia synthesis than $\mathrm{Ru} / \mathrm{TiO}_{2}, \mathrm{Ru} / \mathrm{MgO}$ or $\mathrm{Ru} / \mathrm{CeO}_{2}$. They proposed that strong interactions between $\mathrm{Ru}$ and the support led to rapid electron transfer from the support to the $\mathrm{Ru}$ particle surface. This would greatly promote the cleavage of $\mathrm{N} \equiv \mathrm{N}$ and improve the catalytic activity for ammonia synthesis. Zhou et al. [70] modified mesoporous carbon (MC) by doping $\mathrm{SiO}_{2}$ to change its surface area and pore size and prepared $\mathrm{Ba}-\mathrm{Ru}-\mathrm{K} / \mathrm{MC}$, using modified MC as the support. They found that the particle size of $\mathrm{SiO}_{2}$ and the ratio of $\mathrm{SiO}_{2}$ to MC greatly affected the surface area and the pore size of the modified MC. The catalytic activity for ammonia synthesis increased with the improved surface area found in the modified MC. Lin et al. [71] employed $\mathrm{K}-\mathrm{Ru} / \mathrm{Ba}-\mathrm{ZrO}_{2}$ for ammonia synthesis at high temperatures and found that formation of $\mathrm{BaZrO}_{3}$ and introduction of $\mathrm{K}^{+}$improved electronic conductivity and basicity. Zhang et al. [72] loaded $\mathrm{Ru}$ on $\mathrm{CeO}_{2}$ doped with $\mathrm{Sm}(0$, 2, 5, 7 and $10 \mathrm{wt} \%$ ) and showed that the resultant $\mathrm{Ru} / \mathrm{Sm}_{2} \mathrm{O}_{3}-\mathrm{CeO}_{2}$ was most efficient when the Sm content was 7 $\mathrm{wt} \%$. The introduction of $\mathrm{Sm}^{3+}$ prevented sintering of the catalyst, preserved its morphology by generating more oxygen vacancies and facilitated $\mathrm{CeO}_{2}$ reduction. Pan et al. [73] investigated $\mathrm{Fe}-\mathrm{Ru} / \mathrm{AC}$-catalyzed ammonia synthesis under various conditions (temperature, space velocity, pressure and $\mathrm{H}_{2} / \mathrm{N}_{2}$

Table 3

Ammonia synthesis over Ru-based catalysts, as reported in recent literature.

\begin{tabular}{lccc}
\hline Catalyst & $\begin{array}{c}\mathrm{NH}_{3} \text { concentration } \\
\text { (vol\%) }\end{array}$ & T/ ${ }^{\circ} \mathrm{C}$ & Ref. \\
\hline $4.0 \% \mathrm{Ru} / \mathrm{BaTiO}_{3}$ & 6.96 & 425 & {$[69]$} \\
$\mathrm{Ba}-4.0 \% \mathrm{Ru}-\mathrm{K} / \mathrm{MC} 5$ & 16.4 & 152 & {$[70]$} \\
$\mathrm{K}-4.0 \% \mathrm{Ru} / \mathrm{Ba}^{-\mathrm{ZrO}_{2}}$ & 9.24 & 152 & {$[71]$} \\
$4.0 \% \mathrm{Ru} / \mathrm{Sm}_{2} \mathrm{O}_{3}-\mathrm{CeO}_{2}$ & 13.4 & 152 & {$[72]$} \\
$\mathrm{Fe}-4.0 \% \mathrm{Ru} / \mathrm{AC}$ & 24.4 & 102 & {$[73]$} \\
$5.0 \% \mathrm{Ru} / \mathrm{BaCeO}_{3}$ & 3.2 & 350 & {$[74]$} \\
$4.0 \% \mathrm{Ru} / \mathrm{CeO}_{2}-\mathrm{La}_{2} \mathrm{O}_{3}$ & 13.9 & 177 & {$[75]$} \\
$\mathrm{Sm}-5.0 \% \mathrm{Ru} \gamma-\mathrm{Al}_{2} \mathrm{O}_{3}(\mathrm{~h} 3)$ & 7.4 & 475 & {$[76]$} \\
$5.0 \% \mathrm{Ru} /\left(\mathrm{MgO}-\mathrm{CeO}_{2}\right)$ & 12.6 & 375 & {$[77]$} \\
$\mathrm{K}-5.0 \% \mathrm{Ru} / \mathrm{CNTs}-\mathrm{K}_{-}-5.0 \% \mathrm{Ru} / \mathrm{MgO}$ & 24.3 & 400 & {$[78]$} \\
\hline
\end{tabular}

ratio) and also conducted tests with $\mathrm{Fe} / \mathrm{AC}$ and $\mathrm{Ru} / \mathrm{AC}$ for comparison. Yang et al. [74] discovered that $\mathrm{Ru} / \mathrm{BaCeO}_{3}$ yielded higher catalytic activity than $\mathrm{Ru} / \gamma-\mathrm{Al}_{2} \mathrm{O}_{3}, \mathrm{Ru} / \mathrm{MgO}$, or $\mathrm{Ru} / \mathrm{CeO}$. XRD, HRTEM, XPS, and $\mathrm{H}_{2}$-TPR data confirmed that strong interactions between $\mathrm{Ru}$ and the support facilitated the electron transfer process and that $\mathrm{Ce}^{3+}$ was crucial to the reduction of the $\mathrm{Ru}$ species. Luo et al. [75] applied $\mathrm{Ru} / \mathrm{CeO}_{2}-\mathrm{La}_{2} \mathrm{O}_{3}$ to ammonia synthesis. At $188{ }^{\circ} \mathrm{C}$ and $10 \mathrm{MPa}$, with a $\mathrm{La}_{2} \mathrm{O}_{3}$ content of $10 \%$ and an $\mathrm{NH}_{3}$ concentration of $13.9 \%$, the catalytic activity of $\mathrm{Ru} / \mathrm{CeO}_{2}-\mathrm{La}_{2} \mathrm{O}_{3}$ was apparently higher than that of $\mathrm{Ru} / \mathrm{CeO}_{2}$. These investigators concluded that introduction of $\mathrm{La}_{2} \mathrm{O}_{3}$ facilitated oxygen reduction on the catalyst surface and enhanced stability of the catalyst. Lin et al. [76] prepared Cl-depleted $\mathrm{Ru} / \gamma-\mathrm{Al}_{2} \mathrm{O}_{3}$ through hydrazine reduction and observed that the chlorine content was lowest when the mole ratio of hydrazine to $\mathrm{Ru}$ was 3 and the corresponding catalyst had the highest activity. Saito et al. [77] synthesized a $\mathrm{MgO}^{-\mathrm{CeO}_{2}}$ support through a co-precipitation method and found that its surface area decreased with increasing $\mathrm{CeO}_{2}$ content. The modified $\mathrm{Ru}$ particle distribution was attributed to isolation of $\mathrm{CeO}_{2}$ by amorphous MgO, formed after loading $\mathrm{Ru}$. The partially reduced $\mathrm{CeO}_{2-\delta}(0 \leq \delta \leq 1)$ would facilitate the electron transfer to $\mathrm{Ru}$ and thus promote cleavage of $\mathrm{N} \equiv \mathrm{N}$, whereby the catalytic activity for ammonia synthesis was improved. For example, when $\mathrm{CeO}_{2}$ content was $50 \mathrm{~mol} \%$, the rate of ammonia synthesis in the presence of $\mathrm{Ru} /\left(\mathrm{MgO}-\mathrm{CeO}_{2}\right)$ was 8 times higher than that in the presence of $\mathrm{Ru} / \mathrm{MgO}$. Xu et al. [78] prepared $\mathrm{K}-\mathrm{Ru} / \mathrm{CNTs}-\mathrm{K}-\mathrm{Ru} / \mathrm{MgO}$ by mixing $\mathrm{K}-\mathrm{Ru} / \mathrm{MgO}$ and $\mathrm{K}-\mathrm{Ru} / \mathrm{CNTs}$ (carbon nanotubes) in acetone. They found that this catalyst did not have the drawbacks of $\mathrm{MgO}$, including low basicity of CNTs and poor electron transfer ability, and the activity of the composite catalyst was substantially higher than those of catalysts with single supports (Fig. 12).

\subsection{HCl oxidation (the Deacon process)}

Recycling elemental chlorine is important to reduce $\mathrm{HCl}$ emissions and to meet the increasing demand for $\mathrm{Cl}_{2}$. An attractive route for chlorine recovery is the gas-solid catalytic oxidation of $\mathrm{HCl}$ with air or oxygen, the Deacon reaction. Supported $\mathrm{CuCl}_{2}$ catalysts are the preferred catalysts for the Deacon process, even though they still exhibit serious drawbacks when

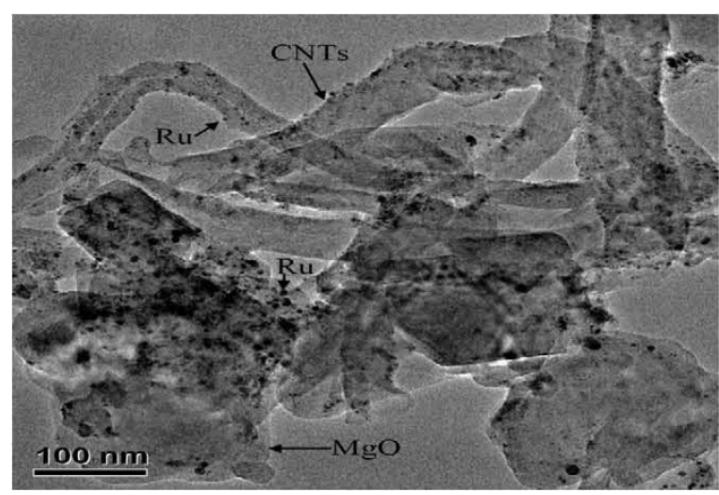

Fig. 12. TEM image of $\mathrm{K}-\mathrm{Ru} / \mathrm{MgO}+\mathrm{K}-\mathrm{Ru} / \mathrm{CNTs}$. Reproduced with permission from Ref. [78]. Copyright 2006, Elsevier. 
used at $430-500{ }^{\circ} \mathrm{C}$. These include limited activity, rapid deactivation due to volatilization of $\mathrm{CuCl}_{2}$ above $400{ }^{\circ} \mathrm{C}$ and corrosion caused by unreacted $\mathrm{HCl}$ and the product $\mathrm{H}_{2} \mathrm{O}$.

$$
4 \mathrm{HCl}+\mathrm{O}_{2} \leftrightarrow 2 \mathrm{Cl}_{2}+2 \mathrm{H}_{2} \mathrm{O}
$$

In 2003, Sumitomo Corporation [79,80] reported novel Ru-based catalysts and applied them in industrial plants. In these catalysts, $\mathrm{TiO}_{2}, \mathrm{ZrO}_{2}, \mathrm{Al}_{2} \mathrm{O}_{3}$ or zeolite were used as supports and the $\mathrm{TiO}_{2}$ supported material showed the highest efficiency. Ru content was within the range of (2-6) wt \%. In addition, some dopants such as $\mathrm{Pd}, \mathrm{Cu}, \mathrm{Cr}, \mathrm{V}$, rare earth compounds or alkali metal compounds were added to the catalysts to enhance their catalytic performance. At standard pressure, a space velocity of $20-1000 \mathrm{~h}^{-1}$ and a temperature of $200-380$ ${ }^{\circ} \mathrm{C}$, the $\mathrm{HCl}$ conversion reached $95.9 \%$ and the lifetime exceeded $16000 \mathrm{~h}$. Nonetheless, the catalytic activity decreased with time and irreversible deactivation usually occurred as a result of the impurities in the $\mathrm{HCl}$ gas or because of errors in technical operation. BASF Corporation [81] used $\mathrm{RuO}_{2}, \mathrm{RuCl}_{3}$, or other $\mathrm{Ru}$ precursors to synthesize $\mathrm{Ru}$ catalysts loaded on $\mathrm{SiO}_{2}, \mathrm{Al}_{2} \mathrm{O}_{3}$, $\mathrm{TiO}_{2}$ or $\mathrm{ZrO}_{2}$. In $\mathrm{HCl}$ oxidation, these investigators observed that the per-pass conversion of $\mathrm{HCl}$ reached (40-90)\%. López et al. [82] studied the mechanism of $\mathrm{HCl}$ oxidation over $\mathrm{RuO}_{2} / \mathrm{TiO}_{2}$ and their DFT studies revealed that the reaction mechanism was consistent with the Mars-van-Krevelen mechanism in 5 steps. These steps were hydrogen abstraction from $\mathrm{HCl}$ (6), recombination of atomic chlorine (7), hydroxyl recombination (8), water desorption (9) and dissociative oxygen adsorption (10).

$$
\begin{aligned}
\mathrm{HCl}+\mathrm{O}^{*}+^{*} & \leftrightarrow \mathrm{OH}^{*}+\mathrm{Cl}^{*} \\
\mathrm{Cl}^{*}+\mathrm{Cl}^{*} & \leftrightarrow \mathrm{Cl}_{2}+2^{*} \\
\mathrm{OH}^{*}+\mathrm{OH}^{*} & \leftrightarrow \mathrm{H}_{2} \mathrm{O}^{*}+\mathrm{O}^{*} \\
\mathrm{H}_{2} \mathrm{O}^{*} & \leftrightarrow \mathrm{H}_{2} \mathrm{O}+{ }^{*} \\
\mathrm{O}_{2}^{*}+2^{*} & \leftrightarrow \mathrm{O}^{*}
\end{aligned}
$$

It was also discovered that $\mathrm{Cl}_{2}$ conversion increased with an increased ratio of $\mathrm{O}_{2}$ to $\mathrm{HCl}$. This change was attributed to the increased 0 concentration on the catalyst surface and the decreased binding energy of $\mathrm{Cl}$. Seitsonen et al. [83] also studied the mechanism of $\mathrm{HCl}$ oxidation over $\mathrm{RuO}_{2}(110) / \mathrm{TiO}_{2}(110)$ using DFT studies. As shown in Fig. 13, a calculated 1 ML (monolayer) $\mathrm{s}-\mathrm{RuO}_{2}$ was loaded on $\mathrm{TiO}_{2}$, affording a well-defined s-RuO $\mathrm{R}_{2} @ \mathrm{TiO}_{2}$ catalyst model.

When $1 / 2 \mathrm{O}_{2}$ was introduced, $\mathrm{O}_{\text {ot }}$ was formed at the $1 \mathrm{f}$-cus (the one-fold under coordinated metal site) site. Some $\mathrm{O}_{\mathrm{ot}}$ sites adsorbed $\mathrm{HCl}$, forming $\mathrm{O}_{\mathrm{ot}} \mathrm{H}$ and $\mathrm{Cl}_{\text {ot. }}$. In addition, other surface $\mathrm{HCls}$ were adsorbed, forming $\mathrm{O}_{\mathrm{ot}} \mathrm{H}_{2}$ and $2 \mathrm{Clot}$ and, finally, $\mathrm{H}_{2} \mathrm{O}$ and $\mathrm{Cl}_{2}$ were desorbed and released. Recently, scientists from Tsinghua University [84] reported a series of monolithic catalysts, composed of FeCrAl alloy or cordierite as the skeleton, (7-12) wt\% supports and (1-3) wt \% active species $\mathrm{RuO}_{2}(110)$. In $\mathrm{HCl}$ oxidation, $87.3 \% \mathrm{HCl}$ conversion was achieved at a low temperature of $280^{\circ} \mathrm{C}$. Over [85] compared activities of several types of $\mathrm{RuO}_{2}$-based catalysts for $\mathrm{HCl}$ oxidation, reporting that the catalytic activity of $\mathrm{RuO}_{2}$-rutile- $\mathrm{TiO}_{2}$ was significantly higher than that of $\mathrm{RuO}_{2}$-anatase- $\mathrm{TiO}_{2}$ and other catalysts (Fig. 14).

In fact, the actual reaction process is more complicated because of differences in properties of the oxygen species on the surface and in oxygen and chlorine coverage. For instance, $\mathrm{O}^{*}$ in

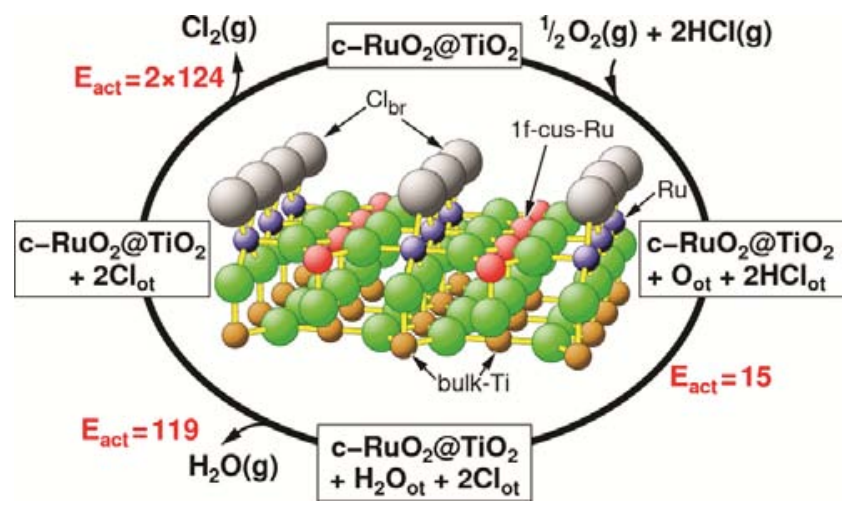

Fig. 13. The catalytic cycle of $\mathrm{HCl}$ oxidation over $1 \mathrm{ML}$ of $\mathrm{RuO}_{2}(110)$ supported on $\mathrm{TiO}_{2}(110)$, starting with a selective and self-limiting replacement of the bridging 0 atoms of s- $\left(\mathrm{RuO}_{2}\right) 1 @ \mathrm{TiO}_{2}$ by bridging chlorine, forming c- $\left(\mathrm{RuO}_{2}\right) 1 @ \mathrm{TiO}_{2}$. The activation energies $E_{\text {act }}$ are given in $\mathrm{kJ} / \mathrm{mol}$. The rate-determining step was identified as association of two neighboring $\mathrm{Cl}$ atoms to form $\mathrm{Cl}_{2}$. Reproduced with permission from Ref [83]. Copyright 2010, American Chemical Society.

Eqs. (6) and (8) can be either $\mathrm{O}_{\text {cus }}$ or $\mathrm{O}_{\mathrm{b}}$ and each should be simulated separately. The lattice oxygen $\mathrm{O}_{\mathrm{b}}$ plays an extremely important role in the process of hydrogen abstraction from $\mathrm{HCl}$ and hydroxyl recombination in water formation. However, the structural oxygen in ruthenium oxide $\left(\mathrm{O}_{b}\right)$ cannot be removed as water $\left(\mathrm{H}_{2} \mathrm{O}_{b}\right)$. In contrast, $\mathrm{O}_{\text {cus }}$ is crucial to formation of hydroxyl groups on the surface and water molecules and the binding energy of the latter is sufficiently low under reaction conditions [82]. Therefore, the Ru-based catalyst must be able to supply enough oxygen species and oxygen vacancies under actual reaction conditions and to prevent catalyst deactivation because of the existence of the $\mathrm{Cl}$ element.

\subsection{Partial oxidation of $\mathrm{CH}_{4}$}

The conversion of methane to syngas is commonly classified into three methods: steam reforming, partial oxidation of $\mathrm{CH}_{4}$ and $\mathrm{CO}_{2}$ reforming. Among those approaches, partial oxidation of $\mathrm{CH}_{4}$ has been recognized as the most efficient method because of its low energy cost, high reaction rate and the conven-

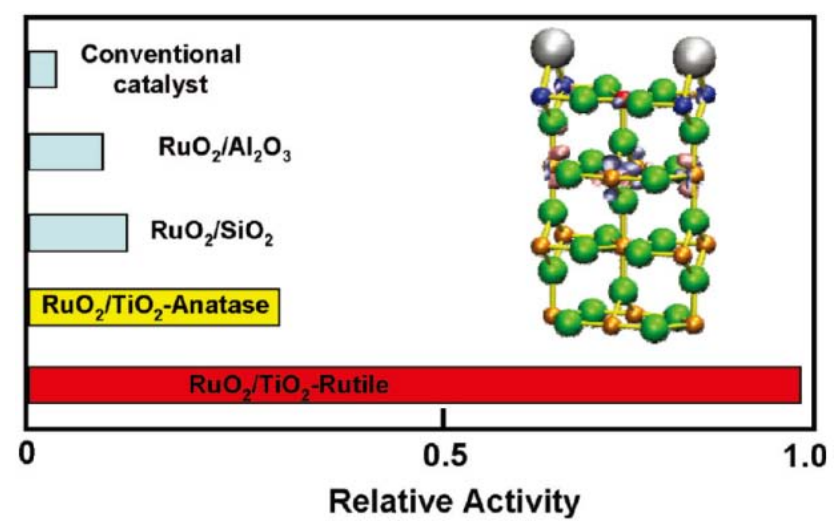

Fig. 14. Relative activities of $\mathrm{RuO}_{2}$-based catalysts for $\mathrm{HCl}$ oxidation, depending on the chosen support. The inset shows $1 \mathrm{ML}$ of $\mathrm{RuO}_{2}(110)$ coated on $\mathrm{TiO}_{2}(110)$. Reproduced with permission from Ref. [85]. Copyright 2012, American Chemical Society. 
ient synthesis of methanol. The partial oxidation of $\mathrm{CH}_{4}$ is often performed on Ni-based catalysts. However, the reaction must be conducted at high temperatures to activate the metal nickel, which causes catalyst deactivation by sintering and carbon deposition $[86,87]$. This is the motivation for developing stable and active catalysts that can operate at the low temperatures. Nishimoto et al. [88] prepared $0.5 \% \mathrm{Ru} / \mathrm{Y}_{2} \mathrm{O}_{3}$ and employed it for partial oxidation of $\mathrm{CH}_{4}$ at $600{ }^{\circ} \mathrm{C}$, with $\mathrm{CH}_{4} / \mathrm{O}_{2}$ ratio $=5$. The $\mathrm{CH}_{4}$ conversion was $27 \%$ with $n(\mathrm{CO}) / n\left(\mathrm{H}_{2}\right)=0.5$ and the selectivity was $75 \%$. No carbon deposit was observed on the catalyst surface after $10 \mathrm{~h}$ of stream reaction. Figen et al. [89] found that complete oxidation was the dominant process within the temperature range of $600-650{ }^{\circ} \mathrm{C}$ and partial oxidation was dominant when the temperature was above $700{ }^{\circ} \mathrm{C}$. Cordierite-supported $\mathrm{Co}, \mathrm{Co}-\mathrm{Ni}, \mathrm{Co}-\mathrm{Ru}, \mathrm{Co}-\mathrm{Ni}-\mathrm{Ru}$ and $\mathrm{Ni}$ catalysts were prepared through the impregnation method and used for partial oxidation of $\mathrm{CH}_{4}$. TG-FTIR results illustrated that $\mathrm{Co}-\mathrm{Ni}-\mathrm{Ru}$ exhibited less carbon deposits than did other materials, primarily because of the catalytic efficiency and stability imparted by $\mathrm{Ru}$. The conversion of $\mathrm{CH}_{4}$ was $93.96 \%$ at $800{ }^{\circ} \mathrm{C}$ and the selectivity to $\mathrm{H}_{2}$ and $\mathrm{CO}$ was $91.81 \%$ and $90.85 \%$, respectively.

\section{Conclusions}

Ru-based catalysts have attracted considerable attention as models for surface science and computational studies. Ru-based catalysts have been well established in various gas-solid catalytic reactions, such as the catalytic oxidation of VOCs, PROX, ammonia synthesis, the Deacon process and partial oxidation of $\mathrm{CH}_{4}$, because of their advantages including high activity, great stability and low yield of byproducts. Catalytic performance is greatly influenced by the physicochemical properties of the catalysts. Morphology and size effects have been well demonstrated in catalytic oxidation of VOCs and PROX and in partial oxidation of $\mathrm{CH}_{4}$. For ammonia synthesis, it is crucial to ensure rapid electron transfer, and this is attributed to strong interactions between $\mathrm{Ru}$ and the support. In the Deacon process, active oxygen species and oxygen vacancies play important roles.
However, challenges still exist in the field of catalytic systems and novel catalysts and, also, their reaction mechanisms should be explored in future research. For example, more formidable catalysts are needed for oxidation of VOCs with multi-pollutants. Many studies have proven that the catalytic performance of Ru-based catalysts for ammonia synthesis is influenced by the nature of the supports. A promising support would show high conductivity and electron-donating ability. It is critical to avoid side reactions and byproducts in PROX and partial oxidation of $\mathrm{CH}_{4}$. Based on the needs we have summarized here, we believe that this review will be beneficial to those addressing future development and application of Ru-based catalysts.

\section{Acknowledgments}

The authors gratefully acknowledge Jianfei Song and Chaoyu Yan for fruitful discussion.

\section{References}

[1] J. Assmann, V. Narkhede, N. A. Breuer, M. Muhler, A. P. Seitsonen, M. Knapp, D. Crihan, A. Farkas, G. Mellau, H. Over, J. Phys.: Condens. Matter, 2008, 20, 184017/1-184017/23.

[2] H. Over, O. Balmes, E. Lundgren, Catal. Today, 2009, 145, 236-242.

[3] S. Hosokawa, H. Kanai, K. Utani, Y. Taniguchi, Y. Saito, S. Imamura, Appl. Catal. B, 2003, 45, 181-187.

[4] S. Aouad, E. Saab, E. Abi-Aad, A. Aboukaïs, Kinet. Catal., 2007, 48, 835-840.

[5] T. Sreethawong, D. Sukjit, P. Ouraipryvan, J. W. Schwank, S. Chavadej, Catal. Lett., 2010, 138, 160-170.

[6] S. H. Lee, J. Han, K. Y. Lee, Korean J. Chem. Eng., 2002, 19, 431-433.

[7] M. Echigo, T. Tabata, Catal. Today, 2004, 90, 269-275.

[8] Y. V. Larichev, B. L. Moroz, V. I. Zaikovskii, S. M. Yunusov, E. S. Kalyuzhnaya, V. B. Shur, V. I. Bukhtiyarov, J. Phys. Chem. C, 2007, 111, 9427-9436.

[9] A. P. Amrute, C. Mondelli, M. A. G. Hevia, J. Perez-Ramirez, J. Phys. Chem. C, 2011, 115, 1056-1063.

[10] C. Elmasides, X. E. Verykios, J. Catal., 2001, 203, 477-486.

\section{Graphical Abstract}

Chin. J. Catal., 2016, 37: 1181-1192 doi: 10.1016/S1872-2067(15)61124-X

\section{Gas-solid catalytic reactions over ruthenium-based catalysts}

Wenbo Shi, Xiaolong Liu, Junlin Zeng, Jian Wang, Yaodong Wei*, Tingyu Zhu*

China University of Petroleum (Beijing);

Institute of Process Engineering, Chinese Academy of Sciences

The activity of $\mathrm{Ru} / \mathrm{RuO}_{2}$ has been illuminated on the atomic scale by the method of combining experiment and theory. Due to their high catalytic activity, Ru-based catalysts are widely used in all kinds of gas-solid reactions including catalytic oxidation of VOCs, preferential CO oxidation, ammonia synthesis, $\mathrm{HCl}$ oxidation and $\mathrm{CH}_{4}$ partial oxidation. The basic properties, oxidation behavior, and theoretical research are also summarized.

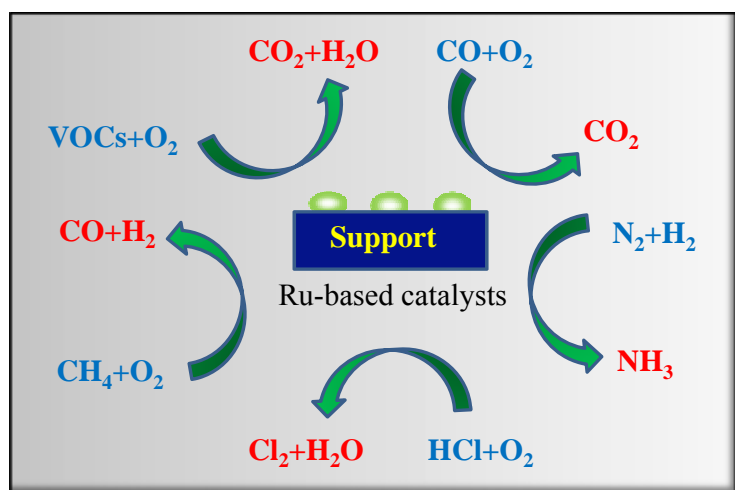


[11] R. Lanza, S. G. Järås, P. Canu, Appl. Catal. A, 2007, 325, 57-67.

[12] M. L. Wang, W. Z. Weng, H. Z. Zheng, X. D. Yi, C. J. Huang, H. L. Wan, J. Natur. Gas Chem., 2009, 18, 300-305.

[13] M. B. Panish, L. Reif, J. Chem. Phys., 1962, 37, 128-131.

[14] R. C. Paule, J. L. Margrave, J. Phys. Chem., 1963, 67, 1896-1897.

[15] J. A. Rard, Chem. Rev., 1985, 85, 1-39.

[16] P. Swain, C. Mallika, R. Srinivasan, U. K. Mudali, R. Natarajan, J. Radioanal. Nucl. Chem., 2013, 298, 781-796.

[17] H. Over, A. P. Seitsonen, Science, 2002, 297, 2003-2004.

[18] H. Over, Y. D. Kim, A. P. Seitsonen, S. Wendt, E. Lundgren, M. Schmid, P. Varga, A. Morgante, G. Ertl, Science, 2000, 287, 1474-1476.

[19] H. Pfnür, G. Held, M. Lindroos, D. Menzel, Surf. Sci., 1989, 220, 43-58.

[20] P. Jakob, M. Gsell, D. Menzel, J. Chem. Phys., 2001, 114, 10075-10085.

[21] H. Over, M. Muhler, Prog. Surf. Sci., 2003, 72, 3-17.

[22] D. W. Goodman, C. H. F. Peden, M. S. Chen, Surf. Sci., 2007, 601, 124-126.

[23] K. Reuter, C. Stampfl, M. V. Ganduglia-Pirovano, M. Scheffler, Chem. Phys. Lett., 2002, 352, 311-317.

[24] T. Engel, G. Ertl, Adv. Catal., 1979, 28, 1-78.

[25] T. E. Madey, H. A. Engelhardt, D. Menzel, Surf. Sci., 1975, 48, 304-328.

[26] C. H. F. Peden, D. W. Goodman, J. Phys. Chem., 1986, 90, $1360-1365$.

[27] C. H. F. Peden, D. W. Goodman, M. D. Weisel, F. M. Hoffmann, Surf. Sci., 1991, 253, 44-58.

[28] A. Böttcher, H. Niehus, S. Schwegmann, H. Over, G. Ertl, J. Phys. Chem. B, 1997, 101, 11185-11191.

[29] C. Stampfl, S. Schwegmann, H. Over, M. Scheffler, G. Ertl, Phys. Rev. Lett., 1996, 77, 3371-3374.

[30] F. Gao, D. W. Goodman, Langmuir, 2010, 26, 16540-16551.

[31] K. Qadir, S. H. Joo, B. S. Mun, D. R. Butcher, J. R. Renzas, F. Aksoy, Z. Liu, G. A. Somorjai, J. Y. Park, Nano Lett., 2012, 12, 5761-5768.

[32] M. J. Patterson, D. E. Angove, N. W. Cant, Appl. Catal. B, 2000, 26, 47-57.

[33] S. Scirè, S. Minicò, C. Crisafulli, C. Satriano, A. Pistone, Appl. Catal. B, 2003, 40, 43-49.

[34] H. L. Tidahy, S. Siffert, J. F. Lamonier, E. A. Zhilinskaya, A. Aboukais, Z. Y. Yuan, A. Vantomme, B. L. Su, X. Canet, G. De Weireld, M. Frere, T. B. Nguyen, J. M. Giraudon, G. Lecleyeq, Appl. Catal. A, 2006, 310, 61-69.

[35] H. Huang, Y. F. Gu, J. Zhao, X. Y. Wang, J. Catal., 2015, 326, 54-68.

[36] A. Yodsa-nga, J. M. Millanar, A. Neramittagapong, P. Khemthong, K. Wantala, Surf. Coat. Technol., 2015, 271, 217-224.

[37] J. L. Zeng, X. L. Liu, J. Wang, H. L. Lü, T. Y. Zhu, J. Mol. Catal. A, 2015, 408, 221-227.

[38] J. Wang, X. Wang, X. L. Liu, T. Y. Zhu, Y. Y. Guo, H. Qi, Catal. Today, 2015, 241, 92-99.

[39] X. L. Liu, J. L. Zeng, J. Wang, W. B. Shi, T. Y. Zhu, Catal. Sci. Technol,, 2016, DOI: $10.1039 /$ c5cy01900a.

[40] J. Wang, X. L. Liu, J. L. Zeng, T. Y. Zhu, Catal. Commun., 2016, 76, $13-18$.

[41] X. L. Liu, J. Wang, J. L. Zeng, X. Wang, T. Y. Zhu, RSC Adv., 2015, 5, 52066-52071.

[42] H. Huang, Q.G. Dai, X. Y. Wang, Appl. Catal. B, 2014, 158-159, 96-105.

[43] Q. G. Dai, S. X. Bai, X. Y. Wang, G. Z. Lu, Appl. Catal. B, 2013, 129, 580-588.

[44] Q. G. Dai, S. X. Bai, J. W. Wang, M. Li, X. Y. Wang, G. Z. Lu, Appl. Catal. $B, \mathbf{2 0 1 3}, 142-143,222-233$.
[45] J. Okal, M. Zawadzki, W. Tylus, Appl. Catal. B, 2011, 101, 548-559.

[46] J. Okal, M. Zawadzki, Appl. Catal. B, 2011, 105, 182-190.

[47] J. Okal, M. Zawadzki, Appl. Catal. B, 2009, 89, 22-32.

[48] T. Mitsui, T. Matsui, R. Kikuchi, K. Eguchi, Top. Catal., 2009, 52, 464-469.

[49] J. Okal, M. Zawadzki, Catal. Lett., 2009, 132, 225-234.

[50] F. J. Gracia, J. T. Miller, A. J. Kropf, E. E. Wolf, J. Catal., 2002, 209, 341-354.

[51] D. Roth, P. Gélin, M. Primet, E. Tena, Appl. Catal. A, 2000, 203, 37-45.

[52] S. Aouad, E. Saab, E. A. Aad, A. Aboukais, Catal. Today, 2007, 119, 273-277.

[53] B. Miranda, E. Díaz, S. Ordóñez, F. V. Díez, Catal. Commun., 2006, 7, 945-949.

[54] S. Hosokawa, Y. Fujinami, H. Kanai, J. Mol. Catal. A, 2005, 240, 49-54.

[55] A. Wolf, F. Schüth, Appl. Catal. A, 2002, 226, 1-13.

[56] H. C. Wu, L. C. Liu, S. M. Yang, Appl. Catal. A, 2001, 211, 159-165.

[57] Y. H. Kim, S. D. Yim, E. D. Park, Catal. Today, 2012, 185, 143-150.

[58] Y. H. Kim, E. D. Park, Appl. Catal. B, 2010, 96, 41-50.

[59] Y. H. Kim, E. D. Park, H. C. Lee, D. Lee, Appl. Catal. A, 2009, 366, 363-369.

[60] Y. H. Kim, E. D. Park, H. C. Lee, D. Lee, K. H. Lee, Catal. Today, 2009, $146,253-259$.

[61] W. Hidenobu, U. Kunihiro, T. Tatsuya, U. Wataru, J. Phys. Chem. C, 2007, 111, 2205-2211.

[62] S. Y. Chin, O. S. Alexeev, M. D. Amiridis, Appl. Catal. A, 2005, 286, 157-166.

[63] O. Goerke, P. Pfeifer, K. Schubert, Appl. Catal. A, 2004, 263, 11-18.

[64] Y. F. Han, M. Kinne, R. J. Behm, Appl. Catal. B, 2004, 52, 123-134.

[65] M. Kitano, S. Kanbara, Y. Inoue, N. Kuganathan, P. V. Sushko, T. Yokoyama, M. Hara, H. Hosono, Nat. Commun., 2015, 6, 6731.

[66] K. I. Aika, H. Hori, A. Ozaki, J. Catal., 1972, 27, 424-431.

[67] H. Bielawa, O. Hinrichsen, A. Birkner, M. Muhler, Angew. Chem. Int. $E d ., 2001,40,1061-1063$.

[68] X. L. Zheng, K. M. Wei, Prog. Chem., 2001, 13, 472-480.

[69] Z. Q. Wang, J. X. Lin, R. Wang, K. M. Wei, Catal. Commun., 2013, 32, 11-14.

[70] Y. P. Zhou, G. J. Lan, B. Zhou, W. Jiang, W. F. Han, H. Z. Liu, Y. Li, Chin. J. Catal., 2013, 34, 1395-1401.

[71] J. X. Lin, Z. Q. Wang, L. M. Zhang, J. Ni, R. Wang, K. M. Wei, Chin. J. Catal., 2012, 33, 1075-1079.

[72] L. M. Zhang, J. X. Lin, J. Ni, R. Wang, K. M. Wei, Catal. Commun., 2011, 15, 23-26.

[73] C. G. Pan, Y. Li, W. Jiang, H. Z. Liu, Chin. J. Chem. Eng., 2011, 19, 273-277.

[74] X. L. Yang, W. Q. Zhang, C. J. Xia, X. M. Xiong, X. Y. Mu, B. Hu, Catal. Commun., 2010, 11, 867-870.

[75] X. J. Luo, R. Wang, J. Ni, J. X. Lin, B. Y. Lin, X. M. Xu, K. M. Wei, Catal. Lett., 2009, 133, 382-387.

[76] B. Y. Lin, R. Wang, J. X. Lin, S. W. Du, X. J. Yu, K. M. Wei, Catal. Commun., 2007, 8, 1838-1842.

[77] M. Saito, M. Itoh, J. Iwamoto, C. Y. Li, K. I. Machida, Catal. Lett., 2006, 106, 107-110.

[78] Q. C. Xu, J. D. Lin, J. Li, X. Z. Fu, Z. W. Yang, W. D. Guo, D. W. Liao, J. Mol. Catal. A, 2006, 259, 218-222.

[79] H. Abekawa, Y. Ito, T. Hibi, US Patent 5908 607, 1999.

[80] K. Seki, JP Patent 2004181 408, 2004.

[81] C. Walsdorff, M. Fiene, C. Adami, E. Strofer, K. Harth, US Patent 0052 718, 2004.

[82] N. López, J. Gómez-Segura, R. P. Marín, J. Pérez-Ramírez, J. Catal., 2008, 255, 29-39. 
[83] A. P. Seitsonen, H. Over, J. Phys. Chem. C, 2010, 114, 22624-22629.

[84] Y. L. Wu, G. Rui, M. D. Yang, J. Dong, X. J. Shi, H. S. Hu, Z. Chen, J. Liu, Y. Chen, CN Patent 101862 674, 2010.

[85] H. Over, J. Phys. Chem. C, 2012, 116, 6779-6792.

[86] R. C. Jin, Y. X. Chen, W. Z. Li, W. Cui, Y. Y. Ji, C. Y. Yu, Y. Jiang, Appl. Catal. A, 2000, 201, 71-80.
[87] Q. G. Yan, W. Z. Weng, H. L. Wan, H. Toghiani, R. K. Toghiani, C. U. Pittman Jr., Appl. Catal. A, 2003, 239, 43-58.

[88] H. Nishimoto, K. Nakagawa, N. O. Ikenga, T. Suzuki, Catal. Lett., 2002, 82, 161-167.

[89] H. E. Figen, S. Z. Baykara, Int. J. Hydrogen Energy, 2015, 40, 7439-7451.

\section{钉基催化剂催化的气固相反应 \\ 施文博 ${ }^{\mathrm{a}, \mathrm{b}, \dagger}$, 刘霄龙 ${ }^{\mathrm{b}, \dagger}$, 曾俊淋 ${ }^{\mathrm{b}}$, 王 健 ${ }^{\mathrm{b}}$, 魏耀东, ${ }^{\mathrm{a},}$, 朱廷钥 ${ }^{\mathrm{b}, \#}$ \\ a中国石油大学 (北京) 重质油国家重点实验室, 北京 102249

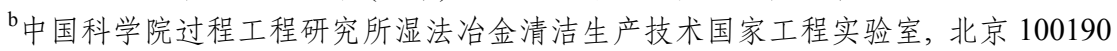

摘要: 催化剂被广泛应用于各种化学品的生产, 从原子尺度了解整个催化反应体系有利于合理设计新型催化剂. 参与气固 相反应的催化剂主要有贵金属催化剂和过渡金属催化剂. 近年来, Ru 基催化剂由于在低温低压下表现出良好的催化活性 而广泛应用于一些气固相反应. 本文对 $\mathrm{Ru}$ 的基本性质、氧化行为以及 $\mathrm{Ru}$ 基催化剂的理论研究进行综述. 介绍了钉基催 化剂参与的气固相反应, 包括挥发性有机物的催化氧化、一氧化碳优先氧化(PROX)、氨合成、氯化氢氧化以及甲烷部分 氧化, 分析了催化性能与理化性质之间的构效关系, 提出了钉基催化剂在相关反应中存在的问题以及未来发展趋势.

$\mathrm{Ru}$ 具有多种氧化态, 在 $\mathrm{Ru}$ 基催化剂参与的气固相反应中, 金属 $\mathrm{Ru}$ 和/或 $\mathrm{RuO}_{2}$ 被认为是活性物种, 通常反应温度在 $400{ }^{\circ} \mathrm{C}$ 以下. $\mathrm{Ru}(0001)$ 晶面在 $\mathrm{O}_{2}$ 存在条件下, 随着氧气含量的不同会从中间态过渡到氧化态, 实验证明该晶面属于 $\mathrm{RuO}_{2}$. 理论研究证实了在反应过程中 $\mathrm{RuO}_{2}$ 的存在, 并提出了核壳结构, 对于其它气固相反应的机理研究有一定启发.

挥发性有机物(VOC)的催化氧化主要集中烷烃、烯烃、芳烃以及卤代烃的催化氧化, 催化剂的理化性质包括颗粒粒径、 价态和晶体结构等对催化活性有很大影响, 并且 Ru 基催化剂对卤代烃的催化氧化表现出良好的抗卤性, 同时多卤代副产 物低于其它贵金属体系. $\mathrm{Ru}$ 基催化剂在低温条件下对 PROX 具有高的活性和选择性, 并且可以有效抑制 $\mathrm{H}_{2}$ 氧化、 $\mathrm{CO}$ 甲 烷化和 $\mathrm{CO}_{2}$ 甲烷化等副反应发生. 氨合成的难点在于 $\mathrm{N} \equiv \mathrm{N}$ 具有很强的解离能, 许多研究表明, 氨合成使用的 $\mathrm{Ru}$ 基催化剂 的催化性能与载体性质密切相关, $\mathrm{Ru}$ 与载体之间强的相互作用使得电子可以迅速地从载体转移到 $\mathrm{Ru}$ 颗粒上, 掺杂其它有 效元素可能会提供更多的氧空位和有效防止高温焙烧导致催化剂烧结. 对于 $\mathrm{HCl}$ 氧化虽然研究较少, 但是 Over 等人对 $\mathrm{HCl}$ 氧化机理进行了深入研究, 并且日本住友化工设计的 $\mathrm{Ru}$ 基催化剂已经商业化. $\mathrm{Ru}$ 基催化剂可以有效降低甲烷部分 氧化的反应温度和压力, 并具有高的选择性和稳定性, 避免副产物生成.

现有催化系统以及新型催化剂开发仍面临诸多挑战, 例如: 对于单一 VOC 氧化过程和多元 VOCs 催化氧化的机理和 动力学需要进一步研究; 对于氨合成需要寻求具有高电导率的载体, 从而将电子快速转移到 Ru 颗粒表面, 使得氨合成在 更低温度下进行; 为了避免副产物生成, 需确保新型 $\mathrm{Ru}$ 基催化剂上PROX和甲烷部分氧化在低温低压条件下进行; Ru 基 催化剂理化性质对活性的影响以及失活等问题需要进一步研究.

关键词: 气固相反应; 钉; 挥发性有机物; 催化氧化; 一氧化碳优先氧化; 氯化氢氧化

收稿日期: 2016-03-28. 接受日期: 2016-04-28. 出版日期: 2016-08-05.

*通讯联系人. 电话/传真: (010)89733939; 电子信箱: weiyd@cup.edu.cn

\#通讯联系人. 电话/传真: (010)82544821; 电子信箱: tyzhu@ipe.ac.cn

†这些作者对本文贡献相同.

基金来源：北京自然科学基金 (8164063); 中国科学院战略性先导科技专项 (B 类) 课题 (XDB05050100).

本文的英文电子版由Elsevier出版社在ScienceDirect上出版(http://www.sciencedirect.com/science/journal/18722067). 